\title{
Constructing corporate identity before the corporation: fashioning the face of the first English joint stock banking companies through portraiture
}

Article

Accepted Version

Newton, L. and Barnes, V. (2017) Constructing corporate identity before the corporation: fashioning the face of the first English joint stock banking companies through portraiture. Enterprise and Society, 18 (3). pp. 678-720. ISSN 1467-2235 doi: https://doi.org/10.1017/eso.2016.90 Available at https://centaur.reading.ac.uk/70075/

It is advisable to refer to the publisher's version if you intend to cite from the work. See Guidance on citing.

To link to this article DOI: http://dx.doi.org/10.1017/eso.2016.90

Publisher: Oxford University Press

All outputs in CentAUR are protected by Intellectual Property Rights law, including copyright law. Copyright and IPR is retained by the creators or other copyright holders. Terms and conditions for use of this material are defined in the End User Agreement. 


\section{CentAUR}

Central Archive at the University of Reading

Reading's research outputs online 
Constructing Corporate Identity before the Corporation: Fashioning the

Face of the First English Joint Stock Banking Companies through

\title{
Portraiture
}

Victoria Barnes (Max Planck Institute for European Legal History) and Lucy Newton $\underline{\text { (Henley Business School, University of Reading })^{1}}$

\begin{abstract}
This article considers how the joint-stock banks established trust within the local marketplace. We undertake a new investigation of pictures of senior bank management. Building on the expansion of the art market in the nineteenth century, joint-stock banks used portraits as a public and visual mechanism to commemorate their successes and accomplishments. Portraiture, as a well-established art form, provided enterprises with a historical legacy that for many did not, as yet, exist. Through the use of portraiture, banks attempted to solidify their identity and add to the sitter's social standing, as well as signal the new organization's reputation for high culture, prestige, and professionalism to those who viewed these artworks. These illustrations personified the company and gave a human face to the early joint-stock economy.
\end{abstract}

\section{Introduction}

This article examines the visual representations of nineteenth century joint-stock banks in portraiture, which were used to establish a corporate identity and build a reputation. The term "corporate identity" is used here to define an organization's presentation of its key values, beliefs, products, services, and strategies to the outside 
world. Lambert describes it, rather broadly, as a projection of the organization, which shows "who you are, what you do, and how you do it."2 It is, like reputation, based on society's perception of the business. A corporation's identity can be controlled and the successful management of it can build and enhance a firm's standing over time. ${ }^{3}$ Within the service sector, these concepts are especially important, as there is no physical product to sell and the service itself is intangible. ${ }^{4}$

Corporate identity manifests itself in a range of ways, including physical and visual forms, such as corporate livery, corporate logos, buildings, architecture, and paintings. ${ }^{5}$ The value of an image over text is due to its simplicity: it can convey complex symbolism without requiring great effort from the receiver in order for those messages to be understood. ${ }^{6}$ Portraiture has been shown to be an effective medium for communication. Guthrey and Jackson identified that the proliferation of pictures showing CEOs in the twenty-first century gave the leader an iconic presence. ${ }^{7}$ Investing in corporate artwork is by no means a recent phenomenon.

The Repeal of the Bubble Act in 1825 furthered the transition from private partnership toward the joint-stock economy in the United Kingdom and led to physical and visual forms of corporate identity being increasingly used. The growth of share ownership and publically traded banking companies followed the passing of the Banking Co-partnership Act 1826. The Act lifted the restriction on the numbers of partners in banks and permitted companies to form with unlimited numbers of owners. ${ }^{8}$ With large groups of shareholders, these banks did not maintain the identity of the private bank, which was built on the personal reputation of a small group of owners. ${ }^{9}$

This research provides a unique view of nineteenth-century banks as organizations that have usually been studied mainly from the viewpoint of management, economic, 
or financial history. ${ }^{10}$ Our aim is to build on existing studies to incorporate a discussion of corporate identity and reputation. Other studies, such as Black's and Booker's, have led the way and shown that joint-stock banks paid close attention to branch design and ensured that their exteriors made a powerful impression on their customers. These authors have both argued that these enterprises used prestigious architecture to instill confidence, trust and, a perception of historic stability. ${ }^{11}$ In the visual representation of the joint-stock banks in this article, we show through the consideration of artwork that images of personalities and people were valuable tools for communication.

Through the bank's commissioning and display of pictures of its managers and directors, a human face became a symbol of the organization. The portrait constituted a painting, photograph, engraving, or medal of a specific individual. It often depicted the likeness of the key decision makers within the bank. The portrayals avoided overt signals of vanity, avarice, or personal wealth, as they showed senior staff within jointstock banks dressed soberly as authoritative male figures. All sitters were, of course, men. It was these images and their characteristics that the early joint-stock banks chose to exhibit. These portraits, we argue, gave the bank a human face and projected an identity, both internally and externally, which personified the company and became its emblem.

This article takes several portraits of bankers as individual case studies, along with literary, textual, and cultural sources, and places them within their social and historical context in order to analyze their purpose, display, and content. We show that in creating an identity and reputation for stability and success, banks gave as much thought, time, and care in designing the exterior of their buildings as they did to dressing its interiors. ${ }^{12}$ These images were sometimes situated inside the bank and 
unveiled as part of a public celebration of the sitter's achievements. Other pictures were also disseminated in print beyond the walls of the bank itself. As the demand for artwork grew, the banker's portrait was sold openly, and it appeared in the public sphere enclosed as an illustration within the burgeoning number of periodicals and newspapers in the popular press.

We begin with an examination of joint-stock banking and the context in which these companies operated in order to establish why they needed to create a positive identity and reputation. This is followed by the second section, which considers the extent to which banks commissioned portraiture and the creation of artwork. The third section establishes the identity of the individual in the portrait and explains why this person was chosen to be commemorated in this permanent fashion. In the fourth section we discuss how the portrait was upheld and recognized the sitter as a model employee, as his performance and narrative in this role was paramount to the success of the symbol. We then analyze the display of a portrait, first inside and then outside the bank itself, finding that these images were shown to a wide public audience. In the sixth section, the article examines portraiture as means of communication and as a signaling device; we then move on to the sitter and his appearance. In the final section, background and props in the pictures are analyzed, as these also contain important symbols and messages.

\section{Background}

Throughout the nineteenth century, joint-stock banks met with vehement opposition from incumbent banking organizations, such as the private banks and the Bank of England, and the representatives in Parliament who fought hard to protect their own interest against the threat of new organizational form. ${ }^{13}$ Added to this was distrust 
from skeptical businessmen, politicians, and a cautious public, all who had witnessed previous bank failures and remained unconvinced that a new form of bank would be any more successful or stable than the old. ${ }^{14}$ Joint-stock companies in general had to combat negative stereotypes; and with a number of high profile cases, they became associated with negligent and poor management. ${ }^{15}$

At a local level, rather than the national one, joint-stock banks encountered a different set of voices and critics. These banks found their feet by distinguishing the new organization from rivals and by competing directly with the other nearby banks. Joint-stock banks, unlike private banks, advanced interest on credit balances, accepted small accounts, exchanged local notes free of charge, and operated more convenient opening hours for their customers. ${ }^{16}$ Offering improved services was one way to overcome opposition and attempt to gain customers in the face of general adversity and disapproving public sentiment.

Joint-stock banks also improved their standing in the local marketplace by establishing positive reputations. This was of prime importance, as banks could not function if they were thought to be in a weak position, experiencing difficulties, or lending frivolously. Customers would not deposit their money if they believed that the bank could not return it on demand. When a joint-stock bank lent money, it provided credit in the form of its own bank notes. The bank's credit would only be useful to a borrower if the notes could be traded as currency and other parties believed that the notes could be redeemable at the bank. Therefore, new financial organizations had to build an identity that could inspire confidence and reduce anxiety for those who might choose to deal with them.

Initially, the new enterprise had no history or record of transactions for consumers to refer to when making their judgments as to whether or not to use their services. The 
majority of joint-stock banks were formed in the nineteenth century as the result of a new promotion rather than as a conversion with a private bank. While mergers between the two were common, the private bank tended to become a branch in the existing joint-stock banks network and the private bankers stayed on at a local level as branch managers. ${ }^{17}$ Continuity at the point of service softened the transition from private to joint-stock bank, and it helped the bank deal with reputational issues of establishing as "new" institutions. Deposit customers or note holders from the private bank who were unhappy with a merger and the new joint-stock bank could, of course, withdraw their funds, exchange their notes, and look to bank elsewhere.

How did potential customers make a decision about who to bank with in this environment? How did joint-stock banks develop a distinct identity and a positive reputation? A potential customer gained hard facts about a bank's performance through written sources such as prospectuses, other reports, and published documents. ${ }^{18}$ However, with little regulation on the minimum threshold for disclosure, ${ }^{19}$ most information gathering occurred on a small scale or interpersonal level. Decisions were often made without reference or access to useful facts or figures, although, as Rutterford shows, the dividend was often one of the most useful indicators. $^{20}$

Joint-stock banks generated the trust of customers by being embedded within the local communities they serviced. ${ }^{21}$ They introduced personalities who became well known as trustworthy businessmen, and presented them with their portraits as a celebration and marker of their individual triumphs. The portrait provided the customer a face and a person to trust: it gave the bank a "personal" identity. The picture identified a senior member of the bank and provided insight into the sitter's character and traits. Through the portrait's display, the bank associated itself with 
those qualities. It showed that the bank employed a model citizen and upheld him as an example to be followed. The following section considers the manner in which banks invested in artwork and began building their reputations.

\section{The Act of Commission}

A proposal for the commission of a portrait tended to take place after an announcement to the bank's shareholders. In one instance, the request came from the shareholders themselves. At the annual general meeting in 1844, the shareholders of the Bradford Banking Company asked if a painting of Samuel Laycock, the bank's manager, could be made. They wished that "a portrait of Mr Laycock, the esteemed manager of the bank, should be taken, to be placed in the Bank, and an engraving thereof to be presented to each subscriber." 22 Afterward, those at the meeting agreed that "a subscription should be entered into among the shareholders" to produce a portrait and a plate. The proposal met with success and "within a few weeks the subscription amounted to more than $£ 600$.” The report clarified that it was a private affair, conceived and paid for by willing shareholders, but that they had paid collectively in a somewhat even or fair way, so "no person was allowed to contribute more than 5 guineas." ${ }^{23}$ This image is shown in Figure 1.24 
Figure 1: Samuel Laycock (1786-1867), manager of the Bradford Banking Company (1827-1867)

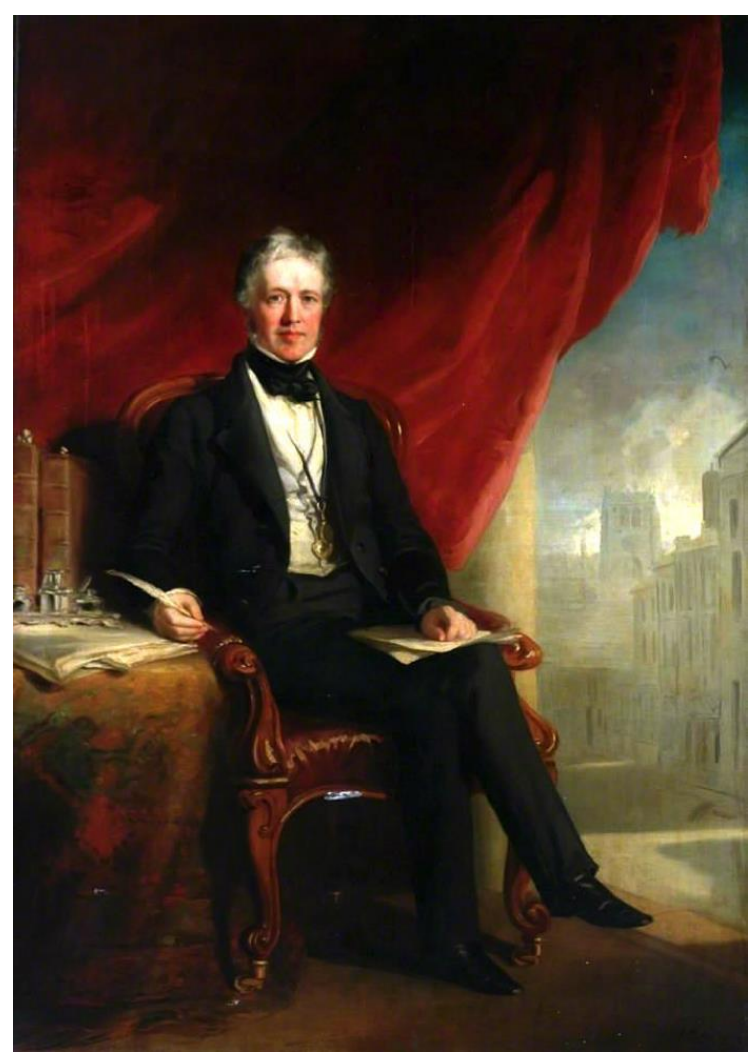

Source: Bradford Art Galleries and Museums, I.F, Bird, 1844.

The Bradford Banking Company established itself in 1827 in Yorkshire as one of the first joint-stock banks to be promoted. It began with a relatively small paid-up capital of $£ 20,000$, and, like many other joint-stock banks, it serviced its local community; in this case, it was people engaged in the wool, worsted, and iron industries. It did not establish branches but operated successfully and independently until 1900, when the London, City and Midland Bank Ltd. acquired it. ${ }^{25}$ The shareholders believed that a key part of its initial success and survival was due to the 
manager, Samuel Laycock. The chairman of the bank presented the plate to Laycock, praising his "judgement, prudence, discretion, and diligence." 26 Laycock's portrait was painted while he was still in office for no other reason than as a sign of gratitude from the bank's shareholders. ${ }^{27}$

Although impromptu celebrations were common, ${ }^{28}$ other companies identified significant dates or marked special occasions and anniversaries, such as retirement or death. When Charles Geach retired as the managing director of the Birmingham and Midland Bank, the shareholders presented him with a portrait (Figure 2), a silver plate set, and a testimonial. ${ }^{29}$ Geach had worked for the firm first as chief manager and later as managing director since its establishment in $1836 . \mathrm{He}$ had seen the bank through from its formation to generating an annual profit of $£ 16,474$ twelve years later in 1848 , and more than $£ 13,000$ per year in 1849,1850 , and $1851 .{ }^{30}$ Even after Geach's departure, his association with the bank did not end. To mark his death, the bank commissioned a medal, which captured his likeness. ${ }^{31}$ 
Figure 2: Charles Geach (1808-1854), Founder, Chief Manager, Birmingham and Midland Bank, 1836-1846, Managing Director, 1846-1854

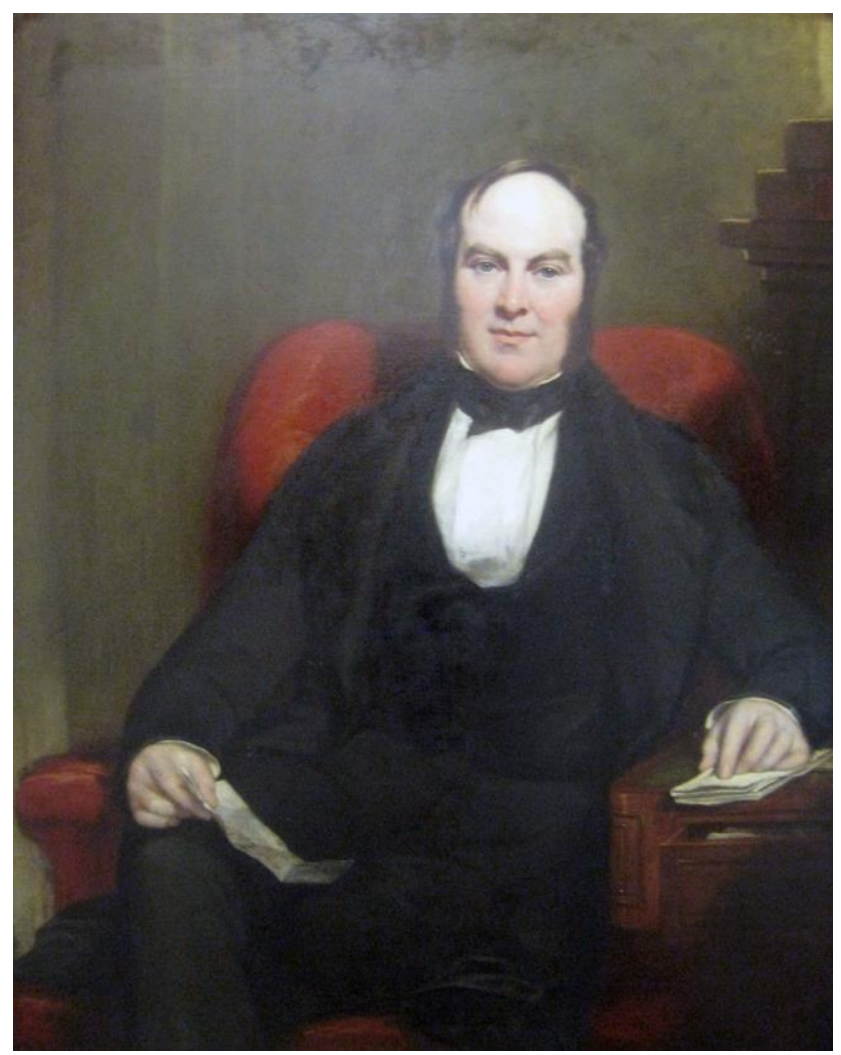

Source: HBSC Group Archives, 1850. J. Partridge.

Indeed, death was an important marker in an individual's history and an occasion that banks tended to record and observe. Daniel Robertson held the position of the general manager of the National Provincial Bank of England from its founding in 1833. As the bank's name suggested, it aimed to serve a large geographical area, and it maintained a large branch network across England and Wales. Robertson retired from this role in 1863 , thereafter continuing in service as an honorary director. On his passing in 1864, the directors of the bank ordered that Baron Marochetti, a 
Sardinian sculptor best known for his work for Queen Victoria, should produce a commemorative marble bust of Robertson (Figure 3). ${ }^{32}$ Unlike Laycock's portrait, a call for subscriptions did not appear to be mooted, which suggested that as the bank directors proposed the idea, they or the bank covered the cost.

Figure 3: Daniel Robertson (1805-1864), bust, General Manager, National Provincial Bank, 1833-1863, Director, 1863-1864.

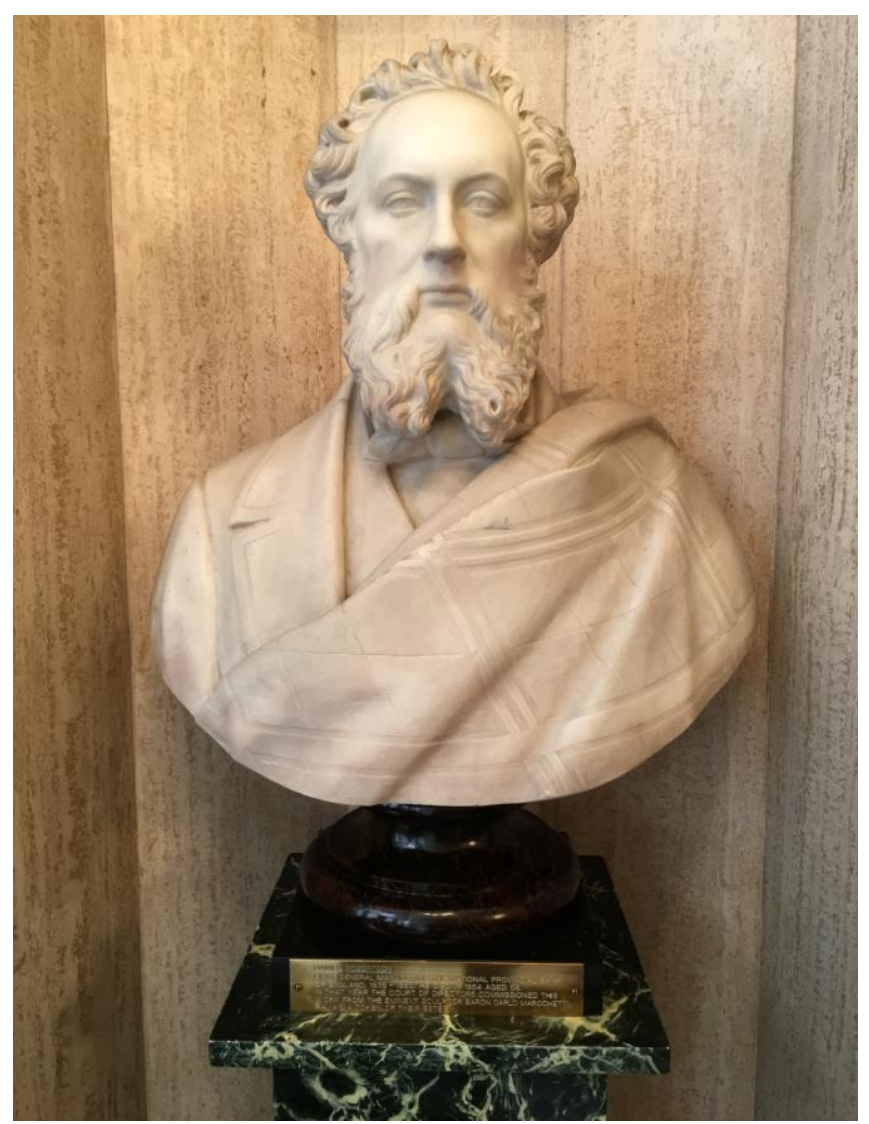

Source: Gibson Hall, site visit 28/7/2016 
The popularity of institutional portraits and the rate of their commissioning or display cannot be enumerated in a reliable way. Retail banks have neither kept all of the artwork from their history nor retained all the details of commission or display. Table 1 provides an inventory of all the pictures of joint-stock bankers produced before 1860, which survive in the major banks in the United Kingdom. Some of the portraits are still used and exhibited inside bank premises or museums, while, for others, little remains known about them and the pictures are held bank's archives. ${ }^{33}$ Research for this article has also revealed a number of images that were produced for joint-stock banks operating in this period are not currently in their possession. ${ }^{34}$ This point, therefore, suggests that investment in paintings was much more common than Table 1 implies. 
Table 1: Portraits of joint-stock bankers in held in bank archives and painted before 1860

\begin{tabular}{|c|c|c|c|c|}
\hline Name & Bank & Role & Material & Date \\
\hline Adam Hodgson & Bank of Liverpool & $\begin{array}{l}\text { Director, 1831- } \\
1834,1835- \\
1839,1840- \\
1844,1845-49 \text {, } \\
1850-1854, \\
1855-1859, \\
1860-1863, \\
\text { Chairman } \\
1835-1839\end{array}$ & Oil & 1837 \\
\hline George Holt & Bank of Liverpool & $\begin{array}{l}\text { Director, 1831- } \\
\text { 1833, Chairman } \\
1847-1849\end{array}$ & Oil & 1831 \\
\hline Edmund Burdekin & Bank of Manchester & $\begin{array}{l}\text { Managing } \\
\text { Director, 1829- } \\
1843\end{array}$ & Oil & Unknown \\
\hline George Bacchus & Birmingham Town and District & $\begin{array}{l}\text { Chairman, } \\
1836-1840\end{array}$ & Oil & Unknown \\
\hline Unknown & Birmingham Town and District & Unknown & Oil & Unknown \\
\hline Unknown & Birmingham Town and District & Unknown & Oil & Unknown \\
\hline
\end{tabular}




\begin{tabular}{|c|c|c|c|c|}
\hline James William Gilbart & London and Westminster Bank & $\begin{array}{l}\text { General } \\
\text { Manager, 1833- } \\
\text { 1860, Director, } \\
1860-1863\end{array}$ & $\begin{array}{l}\text { Oil, photograph, } \\
\text { engraving }\end{array}$ & 1850 \\
\hline Daniel Robertson & National Provincial Bank of England & $\begin{array}{l}\text { General } \\
\text { Manager, 1833- } \\
\text { 1863, Director, } \\
1863-4\end{array}$ & Oil, engraving & 1840 \\
\hline Sir Peter Laurie & Union Bank of London & $\begin{array}{l}\text { Governor of the } \\
\text { Union Bank of } \\
\text { London, 1839- } \\
1861\end{array}$ & Engraving & 1856 \\
\hline
\end{tabular}


Joint-stock banks commissioned portraits, busts, and medals with likenesses of prominent bankers engraved on them at several points in their early history, although this mostly occurred while the banker was in office, on his retirement, or on his death. The proposal to create such an artifact usually came from those within the bank, such as shareholders or directors. The individual, who was chosen to sit for the portrait, and his narrative, was significant as the portrait provided a clear, physical, and permanent link between the sitter and the organization. As the portrait acted to associate the two identities, then the sitter's personality needed to be suitably admirable and the story of his rise retold. We now turn to examine the identity of the sitter in greater detail.

\section{The Sitter's Narrative}

When the portraits were commissioned or unveiled, a short written biography and testimonial usually described the sitter as an individual. It explained his characteristics and qualities, as well as the reasons for his importance and recognition in such a permanent way. As Table 1 shows, those men who found themselves represented in the bank's artwork were male and senior members within the organization. Like James William Gilbart, of the London and Westminster Bank, several began as the general manager and, after retirement, held a position on the board. The bank or its shareholders identified such an individual through the successes in his professional life. It was the sitter's performance in his capacity as an employee and his service as a loyal servant that elevated him to a position thought to be worthy of celebration. 
When a local newspaper reported the commission of the portrait for Samuel Laycock, it explained that the portrait was:

A tribute of respect and appreciation on the part of the subscribers, to A

PUBLIC MAN - to one closely identified with the progress and prosperity of the town - to one whom all classes of this trading community are deeply indebted for the prudence and skill with which he has managed the ... establishment. ${ }^{35}$

The original inscription on the centerpiece of the silver plate presented to Geach, along with his picture, provided a similar vision of the sitter. The gift stood: as a record of the shareholders':

\section{[As a record of the shareholders'] appreciation of the talent, zeal, and energy} displayed by him in the administration of their affairs, and to mark their sense of a management characterised by firmness and considerate kindness, which has raised the bank through a signal course of prosperity to its present flourishing condition..$^{36}$

These endorsements, written on behalf of the bank, perpetuated the bank's version of the individual's narrative and biography. This style of advocacy ensured that the artwork appeared to be given from one party, either the bank directors or its shareholders, to another, with its management and senior staff being recipients. The rhetoric of recognition, and the role and involvement of a second party, ensured that the portrait did
Commented [LMS1]: This needs to start with a full sentence, which is why the bracketed phrase was moved to here. 
not appear as a selfish or vain act of one individual elevating himself. A narrative of achievement surrounded the act.

Not all wished to have their image recorded in this permanent way or would accept such a gracious public tribute. In 1866, at the annual general meeting of the Union Bank of London, the proprietors agreed that the outgoing general manager, Mr. Scrimgeour, should sit for his portrait in commemoration of his achievements for the bank. However, Bankers' Magazine reported that this "was precisely the one good thing to which that gentleman refused to give his countenance. ... He had an inconceivable repugnance to sit for his portrait." 37 After Scrimgeour announced his unwillingness to agree to the shareholders' request, the directors offered a plate instead. A plate was a less personal gift. ${ }^{38}$ Nevertheless, this decision did not pass without criticism, as one London magazine considered the plate to be too cheap and a poor show of the bank's appreciation. ${ }^{39}$

While the style of presentation on a special occasion may have appeared to be a gift for all intents and purposes, the written testimonials explained that the portrait was, in fact, a reward. It served as a response for particular actions or service; it was not merely a present that could or would be given to any of its employees. The act showed that the individual had become exceptional, special, and extraordinary. It suggested that such conduct, which was outside the remits of his employment, should still be remunerated in a way that was fitting and extravagant. The narrative discussed the qualities and conduct worthy of this kind of admiration, and it ensured that the recognition was seen as appropriate. 
On a more pragmatic level, in order for the organization's leadership to have been successful, the enterprise must also have experienced its share of accomplishments too, even if this was some degree of longevity at the very least. For Laycock's portrait, the tributes emphasized the manager's role in enriching the surrounding locality and community and providing "prosperity." 40 Here, it was difficult to distinguish the gap between the actions of a banker and function of a bank. Indeed, both aimed to provide a supply of credit. The gain the community felt was access to finance and increased wealth. Geach had, for example, caused the bank "to flourish" and that statement clearly linked the narrative of the sitter to the institution. ${ }^{41}$

The narrative of a public good and personal achievement in relation to Geach continued with his role as Member of Parliament (MP) for Coventry. In an article in the Illustrated London News, a report recorded how he rose, with very little money and without a "first-rate education," to "embrace the opportunity" of his appointment as clerk at The Bank of England in London at 17 years of age. Geach reportedly worked hard "so that by his own perseverance, and diligent performance" he was able to advance further in the Bank of England branch in Birmingham. He then left to become the manager of the newly open Birmingham and Midland Joint Stock Bank in 1836, at the age of 28, guiding the bank to both stability and prosperity. ${ }^{42}$ Geach progressed from bank manager to managing director, and was eventually elected as the mayor of Birmingham in 1847 and MP for Coventry in $1851 .{ }^{43}$ This article reinforced the history of both the individual and the bank: hard work, diligence, public good, and advancement through talent. 
Sir Peter Laurie, of the Union Bank of London, sat for a painting in $1854 .{ }^{44} \mathrm{He}$ set up and ran his own successful saddlery business, before retiring to concentrate on politics, social reform, and banking. He was elected Sheriff of London, served as a magistrate in the City of Westminster, was elected as an alderman for Aldersgate, before becoming Lord Mayor of London. Laurie became the first chairman of the Union Bank of London in 1839 , and served in this capacity for twenty-two years until his death in 1861 at the age of 83.45 Portraits of such a man, commissioned by a bank, allowed the sitter to accrue more social, economic, and cultural capital at a local level. In some cases, it solidified his position and catapulted him into new situations, as occurred with Geach. Close and visual association with an MP or Lord Mayor of London also enhanced a bank's identity and reputation.

The act of commissioning the portrait, although explicitly celebrating the individual's personal success, said the same about the bank and its accomplishments. Indeed, the simple underlying point here was that the organization had experienced enough success to commemorate its staff and its achievements in an overt and explicit way. The rhetoric and reasoning for a commission said little of the sitter himself and his private life but much about his professional talents or work ethic. Outside a sitter's professional life, these men were generally of good social standing and important within the localized environment and social circles. For example, Geach was active and successful in local business ventures, ${ }^{46}$ as were Liverpool joint-stock bankers George Holt and Adam Hodgson. ${ }^{47}$ As well as being founding directors of the Bank of Liverpool, and later chairing the bank, they were two of the first original directors of the Liverpool- 
Manchester Railway, which opened in 1831. Holt was also the first chairman of the Liverpool and London Globe Insurance Company and was originally a cotton broker. In addition to Hodgson's roles in business, he was active and embedded in the social and political life of Liverpool. ${ }^{48}$ These are examples that a sitter was identified through his professional achievements and, in turn, the organization's identity was linked to his talents.

A portrait of a senior manager commemorated his service and efforts in the successful running of a bank, which had led to prosperity for the local community. Overall, the commission of such an image tended to be articulated as a personal expression and token of gratitude from the bank and its shareholders or directors. Despite its private origins, the portrait became an object for public consumption and conveyed messages about the banker within wider society. We consider the possession and display of portraits by jointstock banks in more detail in the following section.

\section{Display}

This section explores where the portraits of bankers would have been positioned and the audience that would have heard his and the bank's story of success. As banks commissioned portraits to recognize the individual and his achievements, the intention was to complete this celebration by unveiling the portrait when it was finished.

Thereafter, the bank would do what it liked with the portrait. It could throw it away or continue to perpetuate this event and its values through display. 
Before the advent of photography in the twentieth century, it is difficult for the historian to trace exactly how these images were used or where they would have been displayed. Portraits, like any moveable object, did not appear on floor plans. The mechanisms and methods used to disseminate the picture were fairly ambitious and diverse, as the next section will show. These attempts were not recorded centrally or organized to be thought of as comparable to a marketing campaign. ${ }^{49}$ Often, if there is an archival record, it is the artifact itself. Despite the lack of archival material surrounding the portrait, a number of points can be made here with varying degrees of certainty. The first is that we believe that it is highly unlikely that the portraits were discarded or hidden immediately after commission. Aside from their monetary value or the costs associated with commission, the portrait was a picture of an individual, and it was the product of a gesture, a gift from one to another. Destroying or concealing it would probably have been offensive to a large number of people, not the least of which would be the person in the portrait, as well as those who felt close to him or simply thought the expression of gratitude to be appropriate.

While it appears fairly certain that the images were displayed rather than hidden, they were shown from a variety of places. A number of portraits were kept within the bank, although it is less clear where exactly they would have been positioned. For example, the corporate history of the Lancashire and Yorkshire Bank Limited, written in 1922, included images of paintings taken in the early nineteenth century of senior staff from its constituent banks. It recounted that these pictures were displayed in the corresponding branches but did not describe their location within each branch. ${ }^{50}$ 
A number of possible locations existed in each bank, as it contained a number of rooms. In a typical bank, customers would first step into the banking hall. It followed the entrance and functioned like a lobby. The main activity of banking, such as depositing or withdrawing cash, would take place within this room. Stemming off from this reception area, there could be an office for the manager, a private counting room, and possibly a boardroom. Of all these rooms, the banking hall, as a receiving room, would be the prime location for display.

As Figure 3 shows, Daniel Robertson's marble bust was one of the artifacts positioned in the foyer of its new head office in Bishopsgate, London. ${ }^{51}$ When the report from the National Provincial's annual general meeting in 1865 announced that the bust had been commissioned, it also gave some indication of where it would be placed. The report stated that the sculpture was going "to be placed in a prominent position in the Bank's new building, as a mark of respect, which they hope will meet the approbation of the shareholders." 52 The bust would be eventually sited in the entrance to the banking hall. As all who entered the bank would flow into the banking hall, it was where all shareholders and customers could view any image that was displayed there. Exhibition in the area with the greatest footfall was thought to be important in showcasing the commemorative artifact.

Another reason that explains why the banking hall may have been chosen over other areas is that it operated like a reception room; it was the first opportunity to make an impression on customers as they entered the bank. Considerable expense and effort was put into decorating this room. Banking halls were generally large open spaces with tall 
ceilings, which indicated space and grandeur. ${ }^{53}$ Portraiture, like any artwork, would therefore have been entirely in keeping with this striking style of interior design. In Figure 4, a portrait can be seen in the top right-hand corner of a large and imposing banking hall. The image was taken inside a Lloyds Bank branch in Manchester after photography first became widely used in the early twentieth century.

Figure 4: A banking hall in a Lloyd's branch showing a portrait in the top right corner

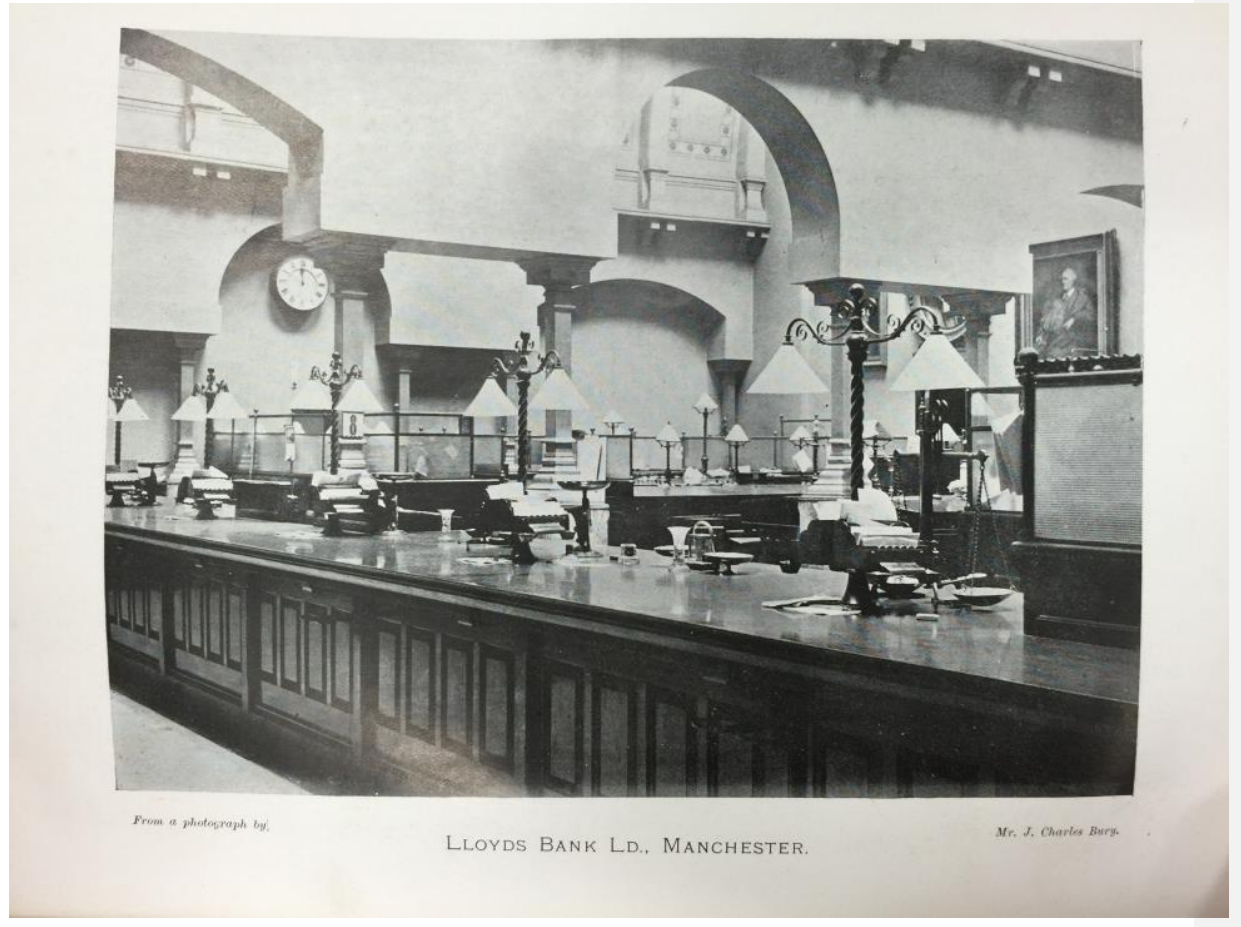

Source: Manchester and Liverpool District Bankers' Institute Magazine, Vol. 1 Nov. 1902-Aug 1905252 
Apart from the hall, another location for display was the boardroom or bank manager's office. Neither possessed the same footfall, atmosphere, or design as the banking hall, but, nevertheless, they were important rooms within the bank. As branches would not have had boardrooms to hold meetings, the manager's office would not have functioned as a private room but rather be used as a place where senior management gathered. It was also a space where customers would have entered to negotiate, open an account, gain credit, or obtain support from the bank. Discussions would take place in this location, away from the crowd so that the customer could reveal confidential information on a one-to-one basis. For banks with branches, a portrait of the general manager in a branch manager's office also reminded staff of the check and balances that existed with the bank's organizational structure. Images in the boardroom held a similar function. Access to the boardroom would have been limited to a select group and largely an internal audience. The images of Laurie, from the Union Bank of London, and Geach, from the Birmingham and Midland Bank (see Figure 2), were both shown in the boardroom. ${ }^{54}$ These pictures also acted as a reminder to those following them in the bank's hierarchy of what they should aspire to do.

The portraits were thus used to communicate and convey a message to shareholders and those using the bank, usually customers but also staff. The portrait was a ubiquitous reminder to staff that someone they knew as a manager was watching, overseeing transactions and the handling of money. They sent an important message about the identity of the individual manager, the ability of the manager to monitor branches and 
staff, and also of the ability of the consumer to clearly recognize who was in charge of their money.

Much like a mug shot, the portrait of a manager ensured that the bankers were permanently identifiable and able to be found. Transparency and openness could inspire confidence in the bank; given that most banking took place at a local level, the men in these portraits were easily recognizable. It also meant that those in the business community were best able to monitor and regulate bankers. As noted earlier, directors of the early joint-stock banks tended to be local, ${ }^{55}$ and as Carnevali found in the case of regional Italian banks, "peer monitoring adds another element to the reduction of moral hazard." 56

With local managers and directors overseeing the running of a company, those in the neighborhoods serviced by the bank would know their faces, and portraits drew attention to the process of managerial supervision in a direct and visible way. In turn, communities had the ability to identify bankers through their portraits and monitor the behavior of those running these financial institutions. The local society of businessmen and its associated social networks operated as an informal monitoring mechanism. They provided a supervisory role that offered a strong disincentive for those who may look to defraud clients, and who faced losing the trust, reputation, and connections so vital to business success. ${ }^{57}$ Likewise, the visibility of the portrait within the bank was important for staff, especially in those banks with branches, in that the image would reinforce the concept of monitoring, even in the absence of these senior individuals. There were exceptions to this behavior and instances in which the portraits were unlikely to have 
been displayed inside the bank so proudly. For example, after the directors of the Bank of Manchester exposed Edmund Burdekin's (Figure 5) embezzlement, he absconded to America; it is doubtful that his portrait remained on show. ${ }^{58}$ Following the bank's failure, Burdekin's image portrayed mismanagement and poor judgment at best, and fraud at worst.

Figure 6: Edmund Burdekin, Managing Director, Bank of Manchester, 1829-1843.

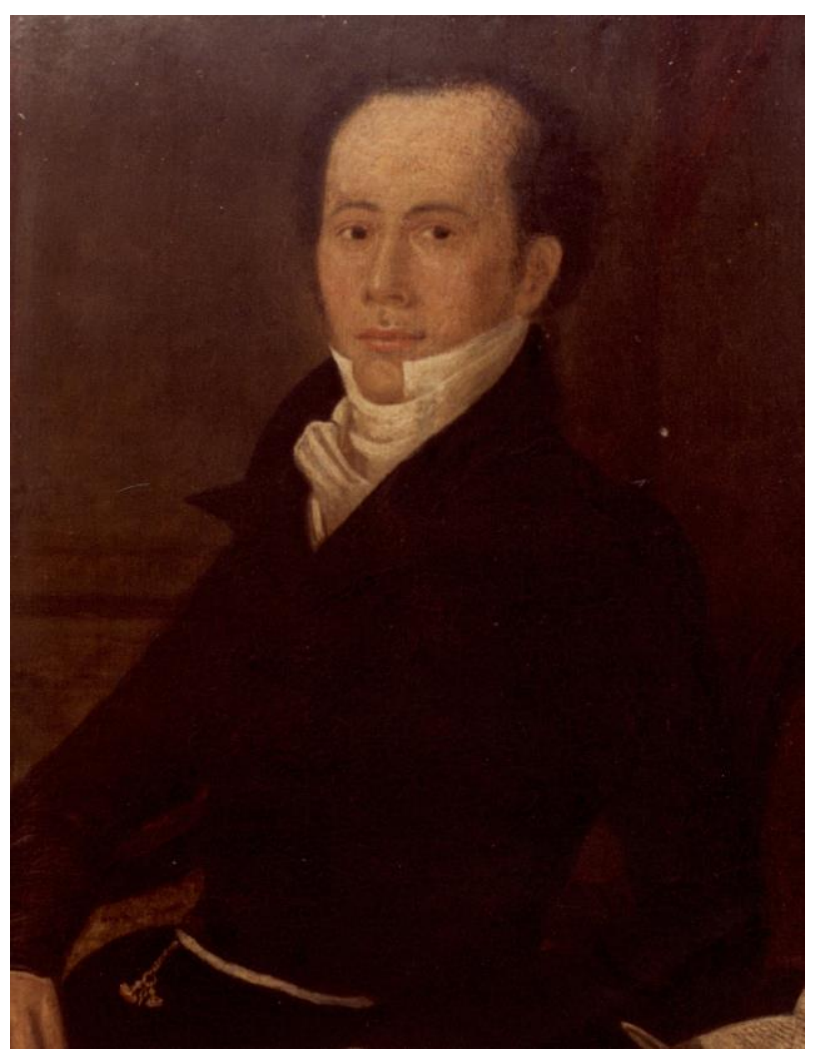

Source: RBS Group Archives, Bank of Manchester, BMA/39. Undated. Unknown artist. 
Joint-stock banks, therefore, commissioned paintings that were likely to have been viewed within the bank by customers and staff. While it was probable that most banks displayed the portrait in the hall or other public areas, examples can be found of images that were shown principally to an internal audience. Publication and illustrations in periodicals and newspapers took this celebration of the individual further than the organization itself, and communicated the success of the bank and the individual associated with it to a wider external audience. The following section discusses these issues in more detail.

\section{Public Dissemination}

The banker's image had a far greater impact than merely on those entering the hall, the manager's office, and the very few who entered the boardroom. Gilbart's portrait, from his time as the general manager of London and Westminster, had a wide circulation and multiple audiences. Its spread was helped by Bankers' Magazine, which advertised copies of his image and sold them to members of the public. ${ }^{59}$ The picture of a young Gilbart (Figure 6) also appeared in 1849 in the Bankers' Magazine as its portrait of the week. ${ }^{60}$ The periodical recognized Gilbart's contribution to contemporary literature on banking and economic thought. The very same print had been published a year earlier in a volume of the Merchants Magazine,${ }^{61}$ and a version of it was acquired by the Royal Society after Gilbart was elected a member in $1846 .{ }^{62}$ A portrait of Gilbart in his later years (Figure 7) was published in the Illustrated News of the World and the Drawing 
Room Portrait Gallery of Eminent Persons in $1860 .{ }^{63}$ This image also appeared on one of the first pages in a corporate history of the London and Westminster Bank, together with the images of other branch managers. ${ }^{64}$

Figure 6: James William Gilbart (1794-1863), General Manager of London and Westminster bank, 1833-1860, Director, 1860-1863

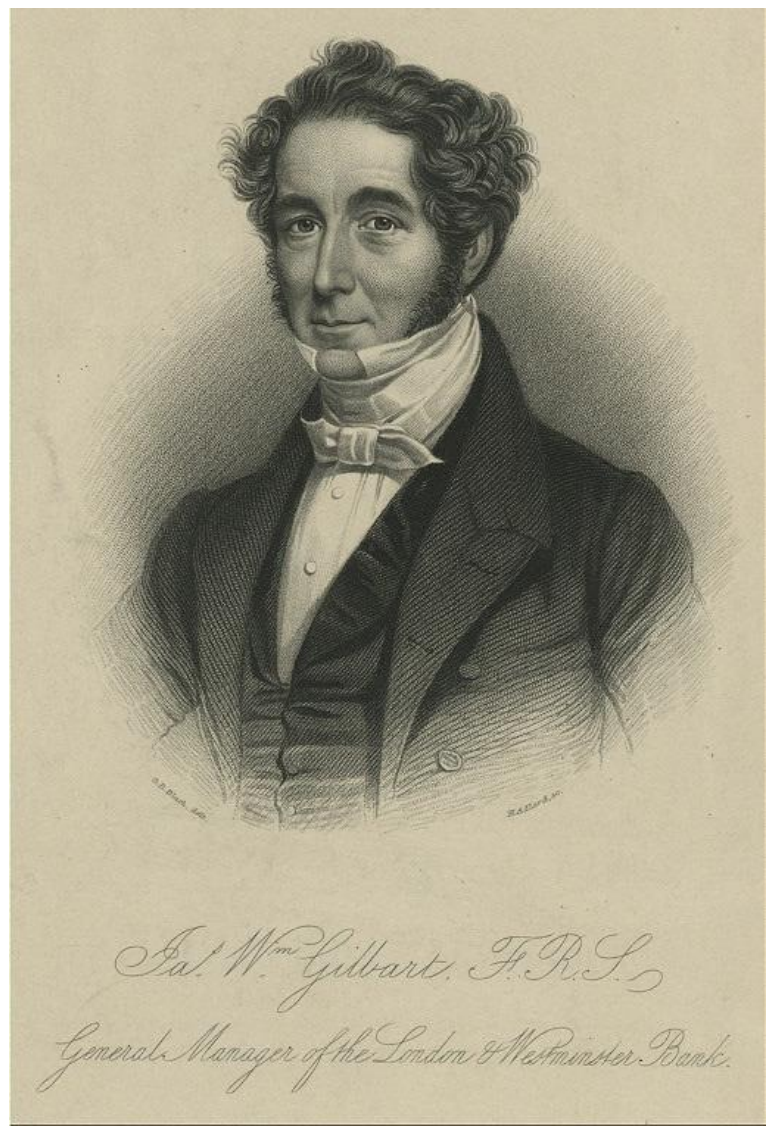

Source: Royal Society Prints, Henry Adlard, c.1850 
Figure 7: James William Gilbart (1794-1863), General Manager of London and Westminster bank, 1833-1860, Director, 1860-1863

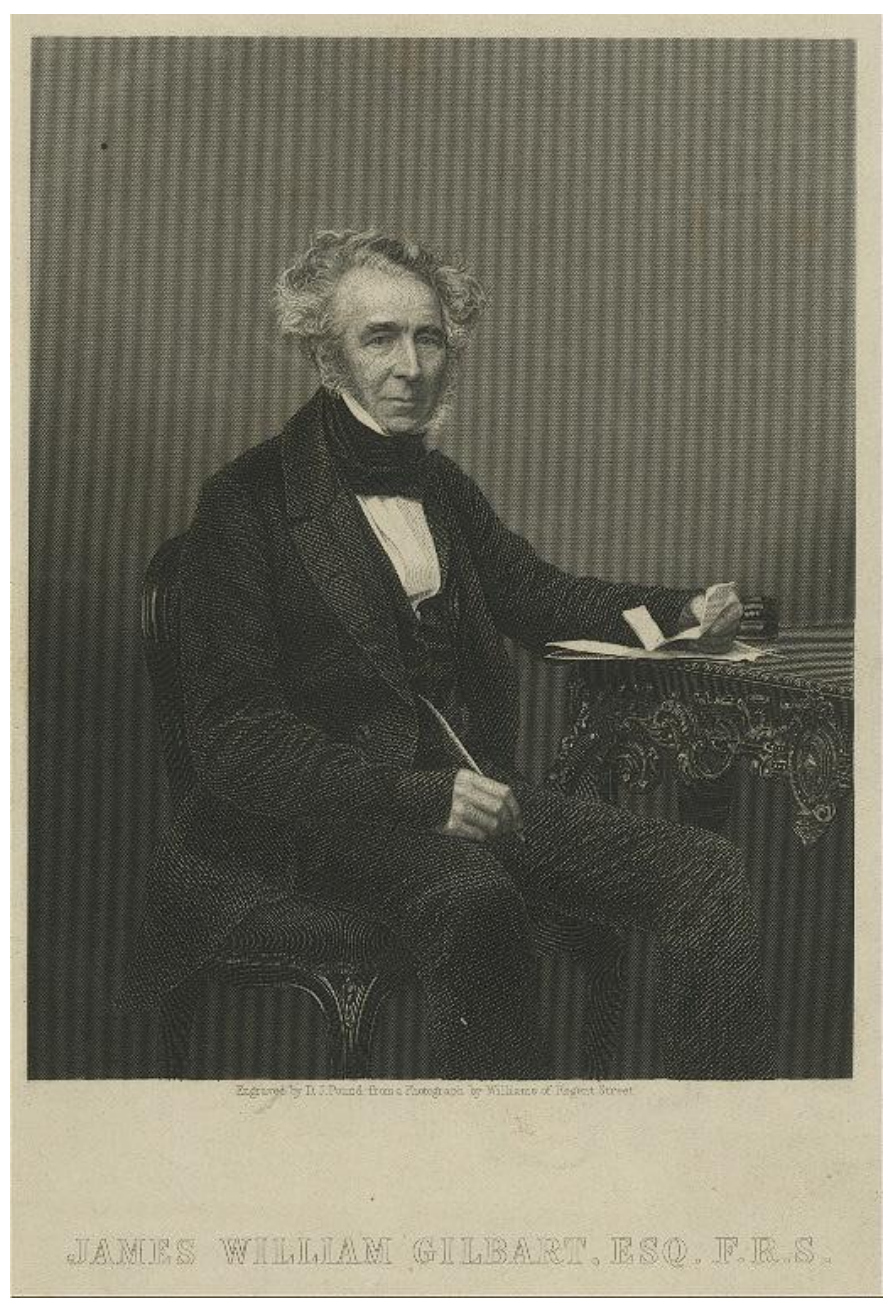

Source: New York Public Gallery, 1243016, circa 1860. 
The success of Gilbart's image was not entirely organic, as he pushed his own persona and the display of his likeness. In his will, Gilbart requested that a framed engraving of his likeness be circulated to those with whom he had been connected in banking. ${ }^{65}$ Gilbart died without a wife, children, or heirs, ${ }^{66}$ so he gave his picture to those whose lives he had touched the most: those in his professional life. He also provided the British Museum with a portrait medal in 1853 , as shown in Figure 8; it was likely to have been issued on the London and Westminster Bank's twentieth anniversary. ${ }^{67}$

Figure 8: James William Gilbart (1794-1863), General Manager of London and Westminster bank, 1833-1860, Director, 1860-1863

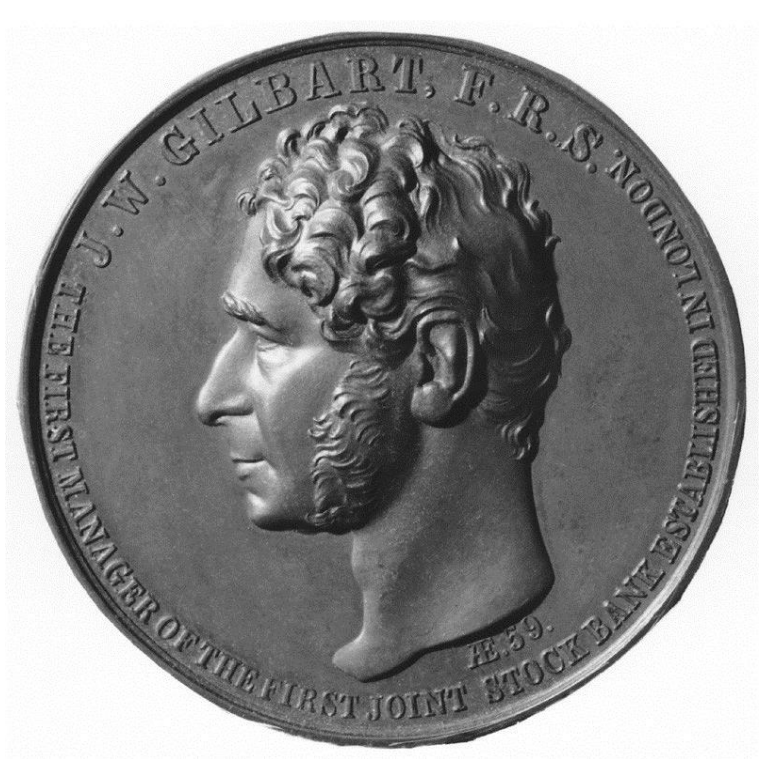

Source: National Portrait Gallery, William Joseph Taylor (1853), bronze medal, 1853 NPG 5756 
While this behavior may not seem especially self-deprecating, Gilbart was not only interested in spreading his own image but also in collecting the images of others. He did so as he sought to build a group identity among bankers. In his memoir, he revealed that in his books he published images of his early colleagues, "whose portraits I associated with my own ... to show my regard." He revealed that he also wrote biographies of others for Bankers' Magazine. ${ }^{68}$ Gilbart appeared to have thought of the portrait as a means of celebrating the bank's success, his own achievements, and those of others in the banking sector. The portrait was thus a means of communicating and introducing an individual to a wide audience.

The faces of London bankers were displayed a number of times in illustrated newspapers, periodicals, museums, and galleries because most of these publications or places were also located in London. These sources tended to feature bankers located nearby in the capital rather than those far away in the provincial towns and cities. It is perhaps unreasonable to expect that those who were not visible within the capital's daily life should be a part of the material culture generated by it. ${ }^{69}$ The picture of the provincial banker may not have been shown as frequently due to a smaller number of platforms. Nevertheless, there were still ways of exhibiting the image without using publications or public venues. With illustrations or engravings, the potential audiences extended beyond those who might see the painting held by the bank. A number of banks appeared to use this strategy. Multiple printed images of Daniel Robertson, manager of the National Provincial Bank of England, existed (see Figure 9).$^{70}$ In the example of Laycock, of 
Bradford Banking Company (see Figure 1), the ability to reproduce the painting was part of the project's very appeal. ${ }^{71}$ Just as the portrait of London banker Gilbart had been distributed in popular London-based periodicals, the provincial banker's picture also appeared in local society.

Figure 9: Daniel Robertson (1805-1864), portrait, General Manager, National Provincial Bank, 1833-1863, Director, 1863-1864.

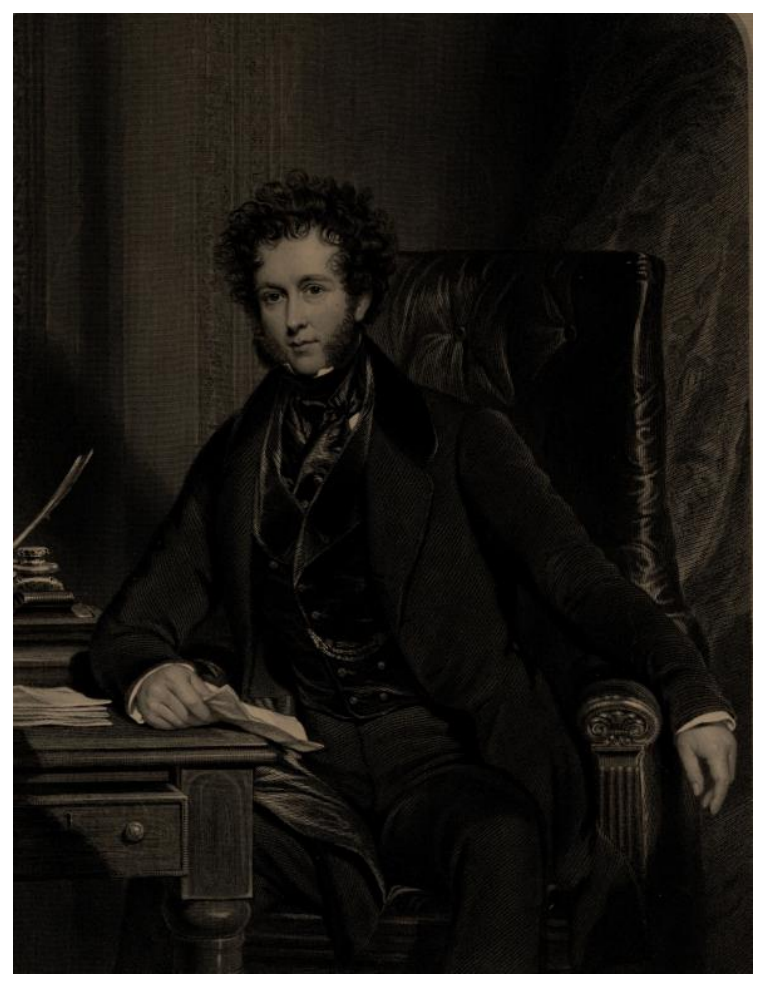

Source: RBS Group Archives, National Provincial, NAT/1313. c.1840. H Robinson (from a painting by J. Partridge). 
Why would the ordinary citizen be interested in possessing a copy of a banker's portrait? As the banker overlooked accounts, granted advances and credit, and advised on investments, his acquaintance and commercial knowledge would be valuable. Marx explained that the banker's position within the social hierarchy, and his power over ordinary society, was due to his role in terms of lending and providing credit. Marx said, citing the words of G. M. Bell, a Scottish bank manager, that the "knit brow of the banker has more influence over ... [individuals than] the moral preaching of his friends.... The advice of the banker is more important ... than that of a clergyman."72 Within local society itself, the banker held a senior position and association with him would be sought after.

Apart from the banker's social standing, these pictures caught attention if they showed the sitter in a favorable light. The Waterford Literary and Scientific Institution commissioned one of Gilbart's many portraits. ${ }^{73}$ A reviewer in The Innkeeper and Trader explained that:

We are not surprised at the Waterford people wishing thus to embellish their hall, for, if we may judge from the portrait we find in the volume under notice, the author is really a very good-looking man, and has a remarkably high forehead. Even now, though close upon threescore [sixty] years and ten, we can scarcely trace a wrinkle in the portrait. The nose is as fine a specimen of the Grecian Roman as we ever saw. ${ }^{74}$ 
For those images with a "good-looking" sitter, the artifact was not thought to be a strange or even "surprising" possession. While London-based bankers found their likeness reproduced in periodicals such as The Bankers' Magazine and the Illustrated London News, those bankers in the provinces appeared in local places. The portraits shown outside of the bank were still capable of building the firm's reputation.

While they may have reached a larger audience, the pictures did not improve the bank's reputation in the same way that a portrait inside the bank itself could. It was not only through the act of commissioning that the sitter and institution entered into a symbiotic and reciprocal relationship. ${ }^{75}$ Possession was more symbolic than the commission itself. ${ }^{76}$ When the painting was kept inside the bank, it served as a physical manifestation and a sign of the sitter's close bond with the organization. The association between the individual and organization was plain and clear for all to see. Without possession, the union between the portrait and the organization was much looser. When an image was displayed outside the bank, it said more of the connection between the individual who possessed the picture and the sitter, and less of a third party, such as the bank. The viewer had to be reminded, through another source, of the organization that employed the sitter.

External display could reinforce the bank's messages of solidity, dependability, hard work, professionalism, achievement, and stability conveyed by the paintings hung in branches if the testimonial reminded the viewer of the bank. The text or narrative that surrounded the portrait often identified him through occupation as a banker and to a 
particular bank, but this detail needed to be read or verbalized, so that the viewer grasped the tie between the two. The bank benefitted from this form of reference to profession when it was made.

By exhibiting these images, both internally and externally, portraits formed a clear and recognizable method to project a corporate identity and build a reputation. These early examples of corporate portraits would be displayed and distributed to assure their customers, and a wider public, of the institution's prestige, success, and solidity. We now turn to examine the symbolism and messages within the portraits themselves in more detail.

\section{Signifying a Historical Lineage}

Over the course of the nineteenth century, banks tapped into the booming interest in artwork. The expansion of the art market in the late eighteenth century and early nineteenth century has been linked to the growth of the upper-middle-class consumer, together with the pace of industrialization. ${ }^{77}$ With a demand for both old masters and new pieces, art formed an increasingly popular way for individuals to communicate their social and economic status, as well as signal their cultural tastes. The first joint-stock banks were, likewise, keen investors in portraiture and understood its value. The contemporary attraction toward paintings ensured that the banker's image was a useful and effective tool for communication. Portraiture itself was favored over the gift of silver plates, as symbols or messages could be implanted within such art. As a device for transmitting ideas, art forms hold an internal meaning of their very own. 
While artwork more generally was sought after, portraiture did not always have the same value or currency among artists themselves. The canvas was often left unsigned and the work unattributed because the artist did not wish to be associated with the product. ${ }^{78}$ Pointon, in her examination of portrait painting as a business in the 1780 s, highlighted how there were a very few artists that were highly successful, such as Reynolds and Gainsborough, but below them were "a host of less distinguished and now forgotten painters." 79

Generally, portrait painting gained popularity in the 1780s. Indeed, while artists may have viewed portraiture as a secondary output, demand ensured that it provided a steady income. At this point, art historians have suggested that it became a dominant form of art for all classes of society. ${ }^{80} \mathrm{By}$ the mid-nineteenth century, the paintings that captured the likeness of individuals had become an increasingly important art form, as evidenced by the opening of the National Portrait Gallery in 1856. Moreover, the Illustrated London News was established in 1842 and, along with other similar periodicals, published engravings, which were frequently images of individuals. Portraits became an established means of communication in galleries and in print.

Although viewing paintings in galleries or periodicals became a mass activity, those recorded in these images were among the elite in society. By its very nature, commissioning a portrait signaled to others that the subject was worthy of recognition and of being recorded. These images would usually be accompanied by a biography of the sitter. ${ }^{81}$ Indeed, the growth of this art form signified a symptomatic shift in general society from an emphasis on a civic and humanist concerns for the general body toward 
personal identity. It marked what Barlow has described as "the beginnings of the ethos of competitive individualism characteristic of industrial mass society." 82

Outside the public arena, private institutions used portraits. Townsend-Gault noted that the three main investors in portraiture were financial institutions, the university, and the military. ${ }^{83}$ Accountants were also keen investors in institutional portraits. ${ }^{84}$ Each sector had different codes and symbols enclosed within their artwork. Townsend-Gault differentiated among these. Financial institutions tended to contain "[s]ome combination of honesty, shrewdness and the prosperity that signifies success," which thus resulted in "greater uniformity." At the university, it was a place "in which many intellectual disciplines are represented"; and for the military, it was where "loyalty and courage ... must always be discernable in the subjects' demeanour." 85 Noting the symbolism and similarities present within portraiture, Foucault asserted that twentiethcentury images preserved "the great nineteenth century effort in discipline and normalization." 86

Indeed, the historic connotations to portraiture as an art form are well noted within social and art theory. Griffrey and Jackson stated, "Portraits have been produced for millennia, and their origins as commemorative images of the ruling elite have had a lasting influence on how, and for whom, portraits are created, and how they function for their intended audiences." ${ }^{\circ 7}$ Adding to this sentiment, Townsend-Gault argued that this "could be interpreted as yet another manifestation of the nostalgia which is expressed in the preservation of the forms of past order." ${ }^{88}$ Indeed, the portrait, whether a Roman- 
sculpted bust or a fifteenth-century Dutch painting, was an art form with a very long history, especially in representing those of wealth and power.

The joint-stock banks capitalized on the growing interest in artwork and visual communication in the nineteenth century. The general commissioning of an institutional portrait indicated a desire for the institution to be perceived as civilized, sophisticated, and cultivated. ${ }^{89}$ Given the history of portraiture as an art form, the artwork itself lent status to the commissioner or owner. Overall, artwork provided the institution with a means to signal its identity and reputation. Griffey and Jackson have argued that the tradition of painting portraits of leaders reinforces the power of an institution and that painted portraits "possess a sense of permanence and prestige." 90 The bankers of the nineteenth century, by sitting for portraits, were thus creating a type of image that was well established as an art form in historical terms and, therefore, suggested a historical legacy that did not, as yet, exist.

\section{Conformity in Dress Code}

Echoing the contemporary prestige attributed to those depicted in portraiture, the content of the image also captured the bank's ambition. Peiss highlighted how appearance has played an important role in the corporation by "conveying through the body a certain set of messages about a firm." This could be achieved, she argued, through dress codes and hairstyles, which "became visual cues that served to unify the corporate or brand identity, put forward a pleasing face to the public, and manage employees." 91 These visual codes were noticeable but were also bound up in intangible social and symbolic meaning. 
While dress and clothing may identify a firm or brand, in these portraits the sitters were from different banks. Even so, they adopted a very similar dress style and conformed to the same type of code or social type. Indeed, in the Victorian period, there was a high level of conformity in attire for both men and women, especially for those outside the very top echelons of society. ${ }^{92}$ What code did bankers aim to communicate by their conformity in dress? Reliability and respectability would be desirable characteristics for any new bank or banker wishing to gain wealthy customers and investors. Craik contended that "respectability... was gauged by conveying an impression of a serious (business-like) demeanour created by wearing sombre clothes." ${ }^{93}$ Kidwell argued that reliability was judged by conservatism in dress, and this would have been considered within the wider context of male fashion and contemporary professional appearance. ${ }^{94}$

The suit, Hollander believed, was "the uniform of official power." In the nineteenth century, it reflected "male interests in the concerted advance of thought, science and commerce, and a lack of concern for capricious and suggestive trifles of any sort." 95 In the 1830 s, the suit tended to have fitted trousers, but by the 1840 s and 1850 s the trouser had given way to a looser fit, usually in "drab colours." 96 The suit was traditionally threepiece. A stiff white shirt and collar were essential, often with a necktie added. ${ }^{97}$ This attire is visible in each of the banker's portraits seen here in this article.

The suit, Breward added, had a "static functionalism," and with it "the successful bourgeois found an image that fixed an otherwise precarious existence with a remarkable symbolic clout." 98 Its symbol, "through the prescription of a sober, business-orientated male costume," Shannon argued, "defined legitimate masculinity." 99 It also linked to the 
“increasing self-consciousness about occupation" that characterized masculinity in the nineteenth century, as well as to paid employment and the development of the professions. ${ }^{100}$ Through the suit, bankers fitted themselves into these contemporary norms and maintained an established code of dress.

As well as clothing, physical appearance also had important social connotations for masculinity and competence. All the figures in this article show that each banker adopted the standard pose found in similar institutional portraiture: with their mouths "gently shut, heads immobile, postures upright, gestures strong."101 Regarding hairstyle, a treatise on hair and skin, written in 1854 , advised its readers that anxiety and stress caused grey hair. It cited the extreme example of the financial panic in 1825-1826, which had resulted in a banker's hair to weaken and turn grey in just three days. ${ }^{102}$ In Robinson's description of the head clerk in the novel The City Banker, she suggested that he went to great lengths to hide his grey hair, as "above all either he wore a wig or his hair was dyed for it contended with the hues of the raven in colour ... [although] he had been grey for years." 103

These images encapsulated the banker's likeness in perpetuity, and, in portraiture at least, they tended to avoid being shown to have greying hair. It is not known if they, like the head clerk, wore a wig or dyed their hair. Perhaps driven by a desire to show that they were in control and prime condition or had not experienced great worry, most were portrayed with dark hair. Geach, although balding, had dark hair. Burdekin had a receding hairline but was presented with black hair. Robertson possessed a youthful and full head of curly hair. Gilbart had a full head of dark hair in images when he was 
younger but had grey hair in images where he was obviously older, seemingly happy for the change in color to be shown, possibly confident of his age, experience, and wisdom. Portraits that were painted permitted a degree of creativity and inventiveness, allowing the sitter to be visualized differently and with the possibility to embellish or remove certain characteristics. It would have been easy to change hair color in an oil painting or print.

Overall, conformity was at the heart of the banker's dress and appearance. In portraiture, by and large, they adhered to contemporary notions of masculinity and authority. As Roper and Tosh asserted, "masculinity is never fully possessed, but must be perpetually achieved, asserted and renegotiated." 104 As these images captured the sitter's likeness in a permanent form, in portraiture at least, masculinity could not be renegotiated thereafter. Thus, dress and appearance were carefully staged or manufactured: loaded with symbolism, suits conveyed ideas of power and maleness. The bankers captured in these portraits adhered to conventional standards of business activity and, in some ways, an expectation of professional dress. Such conformity implied the notions of respectability, reliability, and essentially an unspoken expectation of morally and socially acceptable behavior. The signals were clear: these men did not dress in an extravagant manner and could be trusted with a customer's money.

\section{Utilitarian Settings, Props, and Professionalism}

Moving on from the presentation of the sitter himself, it is necessary to examine the general content that surrounded him. This includes objects, the setting, the size, and the 
style of the portrait itself. Undoubtedly, a portrait centered on the sitter, but objects and accessories added to his persona, even if not as central as clothing or not placed within a prominent location in the portrait. Burke has stated that in portraits, the "postures and gestures of the sitters and the accessories or objects represented in their vicinity follow a pattern and are often loaded with symbolism." 105 Unsurprisingly, portraits of bankers could only be helpful in creating an identity if their content was suitable for achieving these ends.

The joint-stock bankers' postures, accessories, and poses were of a utilitarian nature and played down notions of wealth. Instead, they emphasized the individual's skill and professionalism. Nevertheless, a certain amount of wealth was indicted by the act of commissioning itself, as hiring a particular artist could be expensive. In the case of two senior managers, Geach and Robertson, the bank used the established artist John Partridge to paint their likenesses. He was a successful and prosperous portrait painter and assisted in the movement to form the National Portrait Gallery in London. ${ }^{106}$ In Burdekin's case, the artist did not sign his painting and his identity has not been traced. This was not uncommon, as mentioned above.

As much as the name of the artist, it was the clarity, size, and type of image that also mattered in terms of price. Griffey and Jackson have drawn attention to the link between price and impact by stating that "full-length portraits were the most costly and connoted the most power." 107 The painting of Geach was of good quality, in oils, and about one meter in height and 80 centimeters in width. The framed portrait of Adam Hodgson, director of the Bank of Liverpool, was 111 centimeters wide and 137 centimeters high, 
and that of George Holt (from the same bank) was 83 centimeters wide and 95 centimeters wide. ${ }^{108}$ These images were painted to make an impression with their size and in the materials used.

Not all portraits followed this template. For example, Burdekin's captured only his head and shoulders. This picture would have been cheaper to produce than more complete images, such as of Laycock or Geach. Robertson's likeness was captured in a smaller print (see Figure 9), and therefore it is in no way as imposing in style, size, or effectiveness in signaling power as a life-sized oil painting. Gilbart, in Figure 6, appeared in an engraving, created by Henry Adlard and lithographer George B. Black, measuring 30 centimeters in height and 22 centimeters in width. Both engraved images of Gilbart (see Figures 6 and 7) were not grand oil paintings but rather smaller artifacts that were suitable for reproduction and wide dissemination.

Aside from size, props and accessories constituted another signaling device. Props in portraits showed skill and professional and occupational status. Without an official body accrediting learning and training, ${ }^{109}$ bankers themselves were instrumental in developing their "image" as educated professionals. Their pictures did much in terms of communicating their intellectual abilities. During the nineteenth century, professionals gained an increasing amount of public recognition, as well as greater authority. This can be seen within other institutional images, such as the military, within universities, or of lawyers, accountants, and medical personnel. ${ }^{110}$ However, common threads can be observed across all groups; namely, that of special dress or the centrality of occupation. ${ }^{111}$ While military personnel might be associated with their uniform, for 
professional occupations, objects would be associated with a specialist knowledge or skill set. The accountants examined by Yamey held account books. ${ }^{112}$

Joint-stock banks adopted this technique early on as they used props to identify the specialist skills, knowledge, and studious training needed for the role of banker. Laycock, Robertson, Gilbart, and Geach (see previous figures) sat with quill and notes or bills in their hand. Ironically, Burdekin, who embezzled money, did not hold any bills. It may be argued that the grip on currency or bills acknowledged a "hands-on" approach from these senior individuals and indicated that a customer's money could be trusted directly, and literally, in their hands. With continuity in the use of props, these images reinforce a selfrepresentation and project bankers as a group of trained and educated individuals who could be trusted. ${ }^{113}$

These portraits thus include props that established the sitter's professional role, but the association with an occupation and skill may have had more to do with the artist's selection of props than the sitter's. For example, Nicholson wrote of the eighteenthcentury portrait painter Joseph Wright: he "instinctively associated each sitter with his profession or class, and whatever he holds or displays before him are symbols of his standing or attainments." 114 The bank or sitter, therefore, may not have chosen the exact pose or symbolism involved. Nevertheless, it was the bank's choice to display the resultant image and reproduce the portrait, ensuring the institution's participation in perpetuating this image of professionalism.

The backdrop consistently chosen for joint-stock bankers appeared to be a commercial setting, with the sitter in his working environment, appearing on a chair at his 
desk in the bank or conducting financial activity, reinforcing the nature of his employment. The drawer of the desk was open in both Robertson's and Geach's portraits. It captured them in their normal everyday roles at the bank in the middle of a task. The overall setting and pose chosen presented the sitter in an ordinary setting, thus conveying honesty about the sitter's role in the bank. The open drawer reinforced this message of transparency. All the portraits selected for analysis here convey messages about work, trustworthiness, and leadership through the props, the setting, and the attire of the men within. None convey symbols of personal wealth.

Chairs, on the other hand, did display power. Although, ostensibly, chairs were fairly basic and essential objects for clerical work, they could still be, and were, presented in ostentatious ways and used as symbols of position. ${ }^{115} \mathrm{With}$ a booming furniture and carpentry trade in nineteenth-century Britain, they came in various shapes and sizes. ${ }^{116}$ Indeed, the expense of the chair in many ways also reflected on the subject's wealth. In the portraits of the bankers examined in this article, Laycock and Geach sat in plush red upholstered chairs. Robertson's chair was wooden but elegant and carved. All three are imposing pieces of furniture, high-backed and winged, each with a sense of authority. Within the bank, as senior members of staff, these individuals held both power and position. These portraits and the chairs therein did much to reinforce these notions.

Within society, joint-stock bankers tended to form part of an upwardly mobile professional class rather than being wealthy in their own right or forming part of the landed gentry and social elite. While the portrait alone identified the sitter as part of an existing respectable social elite, these images, although prestigious, and in some cases 
likely expensive, did not involve overly extravagant or rich background details. Jointstock bankers appeared with props that signaled their reputation for skill and competence. Breward explained that within the Victorian era, "professional standing was presented as a position to be striven for and earned." ${ }^{117}$ His thoughts can be applied to the way artists' imagined senior figures within joint-stock banks. Indeed, this became their image in perpetuity. In turn, the professionalism of the individual was linked to the identity of the bank and enhanced the institution's reputation.

\section{Conclusion}

Corporate identity and a positive corporate reputation were important tools for gaining new customers and retaining customers once they conducted business with an organization. This was especially important to new entrants in finance and banking, for example, as they offered intangible services. Art in the form of portraits provided a mechanism to project corporate identity. As a method of reputation building, images served as a passive and simple mechanism to transfer ideas. Communication by image was full of complex symbols, meanings, and concepts that could be rapidly visually interpreted by the viewer.

The art commissioned by joint-stock banks in the nineteenth century was not simply commissioning art for the sake of it. These banks did not invest in images that might be more typical in the general art world, such as the view of a distant landscape or even a luxurious collection of foodstuffs. ${ }^{118}$ Instead, the bank's artwork depicted its senior managers. Through the portrait's display, publication, or distribution, the banker's face, 
along with other personable characteristics and reputation, became fused with that of the banks. The portrait, and the sitter in it, became the bank's symbol.

The signals that were conveyed by these images were threefold. First, while the portrait normally captured an individual of some financial means and power, those appearing in bank portraits posed as members and part of the local community. Indeed, they appeared in contemporary dress and their style followed and changed with normative social conventions. Although commissioning portraiture could have been an expensive act, bank managers were not posed to appear lavish or flamboyant. Instead, the joint-stock bankers posed in professional dress with artifacts that were associated with the specialist skills required to act as a safe, prudent, and competent banker.

Second, portraiture provided new banks with a perception of historic legacy, sophistication, and gravitas. Even with widespread distrust, joint-stock banks were able to successfully establish local reputations for trustworthiness and respectability. Portraiture itself was a long-established art form. These images projected notions of history and the past, even where it did not exist. The act itself of commissioning or owning art suggested that bankers, as new entrants, had an interest outside of profit making and in high culture. It provided the bank with a reputation for gentlemanly and responsible behavior. It was also a reminder for staff and customers alike that those monitoring the performance of a bank and its branches - the sitter in the picture - would enforce this behavior. To shareholders and the wider public, portraits offered reassurance and confirmation of solidity and accountability. 
Finally, above all, it was the banker's standing within society and function as a lender of money that ensured that he was accepted as being important enough or worthy of having his likeness commemorated in art. Indeed, the social standing of bankers meant that portraits would be suitable for distribution and display in locations outside of the sitter's bank. Ownership of these images implied the connectedness of the owner to the subject. The bank manager held information and the confidence of his customers within his community. As he could promote local wealth, connections to the bank were a silent sign of cohesion, importance, and propriety. Without his social position, his picture could not have been used as an easily accepted mechanism to assert the bank's identity and reputation.

The portraits were not simply of human faces. Instead, they gave the company an identity. The face of the bank manager became synonymous with the image of the bank. He carried out customer-related duties and appeared in his painting as a man of professional and commercial knowledge. As a lender of money who held a senior position within his local community, this visual representation would apply to the bank as much as it would do the sitter. By commissioning, displaying, and disseminating the manager's portrait, it connected the two inseparably: it communicated his and the company's reputation for competence and care to those likely to see it within the local business environment and beyond. 


\section{Bibliography of Works Cited}

Books

Ackrill, Margaret, and Leslie Hannah. Barclays: The Business of Banking, 1690-1996. Cambridge: Cambridge University Press, 2008.

Alborn, Timothy L. Conceiving Companies: Joint Stock Politics in Victorian England. London: Routledge, 2002.

Anderson, John R. Cognitive Psychology and Its Implications, 7th ed. New York: Worth Publishers, 2009.

Anon. The Story of the Lancashire \& Yorkshire Bank Limited, 1872-1922. Manchester, UK: Sherratt \& Hughes, 1922.

Balmer, John M. T., and Stephen A. Greyser. Revealing the Corporation: Perspectives on Identity, Image, Reputation, Corporate Branding, and Corporate-Level Marketing : An Anthology. London: Routledge, 2003.

Bayer, Thomas M., and John Page. The Development of the Art Market in England: Money as Muse, 1730-1900. London: Pickering and Chatto, 2011.

Booker, John. Temples of Mammon: The Architecture of Banking. Edinburgh: Edinburgh University Press, 1992.

Bourdieu, Pierre. Outline of a Theory of Practice. Cambridge: Cambridge University Press, 1977.

Breward, Christopher. The Hidden Consumer: Masculinities, Fashion and City Life 1860-1914. Manchester, UK: Manchester University Press, 1999. 
Burke, Peter. Eyewitnessing: The Uses of Images as Historical Evidence. Ithaca, NY: Cornell University Press, 2001.

Byrde, Penelope. The Male Image: Men's Fashion in Britain, 1300-1970. London: Batsford, 1979.

Chandler, George. Four Centuries of Banking, vol. 1. London: B. T. Batsford, 1964.

Cooke, Colin Arthur. Corporation, Trust and Company: An Essay in Legal History. Cambridge, MA: Harvard University Press, 1951.

Craik, Jennifer. The Face of Fashion: Cultural Studies in Fashion. London: Routledge, 1994.

Crick, Wilfred Frank, and John Edwin Wadsworth. A Hundred Years of Joint Stock Banking. London: Hodder \& Stoughton, 1936.

Cudworth, William. Historical Notes on the Bradford Corporation: With Records of the Lighting and Watching Commissioners and Board of Highway Surveyors. Bradford, UK: T. Brear, 1881.

Davidoff, Leonore, and Catherine Hall. Family Fortunes: Men and Women of the English Middle Class 1780-1850. 2nd ed. London: Routledge, 2003.

De Marly, Diana. Fashion for Men: An Illustrated History. London: Batsford, 1985.

Ellison, Thomas. The Cotton Trade of Great Britain: Including a History of the Liverpool Cotton Market and of the Liverpool Cotton Brokers' Association. London: E. Wilson, 1886. 
Foucault, Michel. Power/Knowledge: Selected Interviews and Other Writings, 19721977. Edited by Colin Gordon. Translated by Colin Gordon, Leo Marshall, John Mepham, and Kate Soper. New York: Pantheon Books, 1980.

Gilbart, James William. A Record of the Proceedings of the London and Westminster Bank during the First Thirteen Years of Its Existence; with Portraits of Its Principal Officers. London: R. Clay, 1847.

The Elements of Banking. London: Longman, Green, Longman, 1860.

Green, Edwin. Debtors to Their Profession: A History of the Institute of Bankers, 18791979. London: Methuen, 1979.

Harris, Neil. Cultural Excursions: Marketing Appetites and Cultural Tastes in Modern America. Chicago: University of Chicago Press, 1990.

Hollander, Anne. Sex and Suits. New York: Knopf, 1994.

Holmes, A. R., and Edwin Green. Midland: 150 Years of Banking History. London: Batsford, 1986.

Lamoreaux, Naomi R. Insider Lending: Banks, Personal Connections, and Economic Development in Industrial New England. Cambridge: Cambridge University Press, 1996.

Marx, Karl. Capital: The Process of Capitalist Production as a Whole. Edited by Frederick Engels. Translated by Ernest Untermann. Chicago: Charles H. Kerr, 1909. 
McCracken, Grant David. Culture and Consumption: New Approaches to the Symbolic Character of Consumer Goods and Activities. Bloomington: Indiana University Press, 1990.

Michie, Ranald C. Guilty Money: The City of London in Victorian and Edwardian Culture, 1815-1914. London: Pickering and Chatto, 2009.

Nicolson, Benedict. Joseph Wright of Derby: Painter of Light: Text and Catalogue. London: Paul Mellon Foundation for British Art, 1968.

Orbell, John, and Alison Turton. British Banking: A Guide to Historical Records. Aldershot, UK: Ashgate, 2001.

Ponsonby, Margaret. Stories from Home: English Domestic Interiors, 1750-1850. Aldershot, UK: Ashgate Publishing, Ltd., 2013.

Robinson, Emma. The City Banker; Or, Love and Money, vol. 1. London: Charles J. Skeet, 1856.

Scammell, W. M. The London Discount Market. London: Elek, 1968.

Schama, Simon. The Face of Britain: The Nation through Its Portraits. London: Viking, 2015.

Schulz, Majken, Mary Jo Hatch, and Mogens Holten Larsen, eds. The Expressive Organization: Linking Identity, Reputation, and the Corporate Brand. Oxford: Oxford University Press, 2000.

Shannon, Brent. The Cut of His Coat: Men, Dress, and Consumer Culture in Britain, 1860-1914. OhioInsert cityAthens: Ohio University Press, 2006. 
Swindells, Thomas. Manchester Streets and Manchester Men. 2nd ed. Manchester, UK: J. E. Cornish, 1907.

Sykes, Joseph. The Amalgamation Movement in English Banking, 1825-1924. Insert city, eountryLondon: P.S. King \& Son, Limited, 1926.

Taylor, James. Creating Capitalism: Joint-Stock Enterprise in British Politics and Culture, 1800-1870. Woodbridge, UK: Boydell \& Brewer Ltd., 2014.

West, Shearer. Portraiture. Oxford: Oxford University Press, 2004.

Wilson, Sarah. The Origins of Modern Financial Crime: Historical Foundations and Current Problems in Britain. London: Routledge, 2014.

Wilson, Sir Erasmus. Healthy Skin: A Popular Treatise on the Skin and Hair: Their Preservation and Management. 2nd ed. Philadelphia: Blanchard and Lea, 1854.

Wu, Chin-Tao. Privatising Culture. Revised ed. London: Verso, 2003.

Yamey, Basil. Art and Accounting. New Haven, CT: Yale University Press, 1989.

Articles and Chapters in Books

Ames, Kenneth L. "Material Culture as Nonverbal Communication: A Historical Case Study.” Journal of American Culture 3, no. 4 (December 1, 1980): 619-641. doi:10.1111/j.1542-734X.1980.0304_619.x

Bailey, Cheryl. "The Circular to Bankers.” Bulletin: Newsletter from the European Association of Business Historians 1999, no. 2: 20-21. 
Baker, Michael J., and John M. T. Balmer. "Visual Identity: Trappings or Substance?"

European Journal of Marketing 31, no. 5/6 (June 6, 1997): 366-382.

doi:10.1108/eb060637

Barlow, Paul. "Facing the Past and Present: The National Portrait Gallery and the Search for the 'authentic' Portraiture.” In Portraiture: Facing the Subject, edited by Joanna Woodall, 219-238. Manchester, UK: Manchester University Press, 1997.

Bickerton. David. "Corporate Reputation versus Corporate Branding: The Realist Debate.” Corporate Communications: An International Journal 5, no. 1 (March 1, 2000): 42-48. doi:10.1108/13563280010317578

Black, Iain S. "Spaces of Capital: Bank Office Building in the City of London, 18301870.” Journal of Historical Geography 26, no. 3 (July 1, 2000): 351-375. doi:10.1006/jhge.2000.0234.

__. "Symbolic Capital: The London and Westminster Bank Headquarters, 1836-38." Landscape Research 21, no. 1 (March 1, 1996): 55-72. doi:10.1080/01426399608706475

British Museum. "James William Gilbart (Biographical Details).” British Museum, accessed September 14, 2016.

www.britishmuseum.org/research/search_the_collection_database/term_details.as px?bioId $=123622$

Carnevali, Francesca. "Between Markets and Networks: Regional Banks in Italy." Business History 38, no. 3 (July 1, 1996): 84-100. doi:10.1080/00076799600000096 
Davison, Jane. “[In]visible [In]tangibles: Visual Portraits of the Business Élite.”

Accounting, Organizations and Society 35, no. 2 (February 2010): 165-183. doi:10.1016/j.aos.2009.03.003

Einwiller, Sabine, and Markus Will. "Towards an Integrated Approach to Corporate Branding: An Empirical Study.” Corporate Communications: An International Journal 7, no. 2 (June 1, 2002): 100-109. doi:10.1108/13563280210426160

Freeman, Mark, Robin Pearson, and James Taylor. "Law, Politics and the Governance of English and Scottish Joint-Stock Companies, 1600-1850.” Business History 55, no. 4 (June 1, 2013): 636-652. doi:10.1080/00076791.2012.741971

Garnett, Philip, Simon Mollan, and R. Alexander Bentley. "Complexity in History: Modelling the Organisational Demography of the British Banking Sector.” Business History 57, no. 1 (January 2, 2015): 182-202. doi:10.1080/00076791.2014.977876

Graves, R. E. “Partridge, John (1789-1872),” rev. Charles Noble. In Oxford Dictionary of National Biography. Oxford University Press, 2004-. Accessed October 2016, http://dx.doi.org/10.1093/ref:odnb/21485

Griffey, Erin, and Brad Jackson. "The Portrait as Leader: Commissioned Portraits and the Power of Tradition.” Leadership 6, no. 2 (May 1, 2010): 133-157. doi:10.1177/1742715010363207

Guthey, Eric, and Brad Jackson. "CEO Portraits and the Authenticity Paradox.” Journal of Management Studies 42, no. 5 (July 1, 2005): 1057-1082. doi:10.1111/j.14676486.2005.00532.x 
Hansen, Per H. “Organizational Culture and Organizational Change: The Transformation of Savings Banks in Denmark, 1965-1990.” Enterprise \& Society 8, no. 4 (December 2007): 920-953. doi:10.1017/S1467222700006492

Hoeken, Hans, and Lenneke Ruikes. “Art for Art's Sake? An Exploratory Study of the Possibility to Align Works of Art With an Organization's Identity.” Journal of Business Communication 42, no. 3 (July 1, 2005): 233-246. doi:10.1177/0021943605277111

Kidwell, Claudia Brush. “Gender Symbols or Fashionable Details?” In Men and Women: Dressing the Part, edited by Claudia Brush Kidwell and Valerie Steele, 124-143. Washington, DC: Smithsonian, 1989.

Kinsey, Sara. "Geach, Charles (1808-1854).” In Oxford Dictionary of National Biography. Oxford University Press, 2004-. Accessed October 2016, http://dx.doi.org/10.1093/ref:odnb/49133

Lambert, Andrew. “Corporate Identity and Facilities Management.” Facilities 7, no. 12 (December 1, 1989): 7-12. doi:10.1108/eb006515

Markwick, Nigel, and Chris Fill. “Towards a Framework for Managing Corporate Identity." European Journal of Marketing 31, no. 5-6 (June 6, 1997): 396-409. doi:10.1108/eb060639

McConnell, Anita. “Laurie, Sir Peter (1778-1861).” In Oxford Dictionary of National Biography. Oxford University Press, 2004-. Accessed October 2016. http://dx.doi.org/10.1093/ref:odnb/16133 
Napier, Christopher. "United Kingdom.” In A Global History of Accounting, Financial Reporting and Public Policy: Europe, edited by Gary John Previts, Peter Wolnizer, Peter Walton, and P. W. Wolnizer, 243-270. Bingley, UK: Emerald Group Publishing, 2010.

Nenadic, Stana. "Portraits of Scottish Professional Men in London, c.1760-1830:

Careers, Connections and Reputations.” Journal for Eighteenth-Century Studies 34, no. 1 (March 1, 2011): 1-17. doi:10.1111/j.1754-0208.2011.00348.x

Newton, Lucy. "The Birth of Joint-Stock Banking: England and New England

Compared.” Business History Review 84, no. 1 (March 2010): 27-52. doi:10.1017/S0007680500001239

Newton, Lucy, and Victoria Barnes. "Virtuous Banking: The Role of the Community in Monitoring English Joint-Stock Banks and Their Managements in the Nineteenth Century." In The Challenges of Capitalism for Virtue Ethics and the Common Good: Interdisciplinary Perspectives, edited by Kleio Akrivou and Alejo Jose G. Sison, 62-74. Northampton, MA: Edward Elgar Publishers, 2016.

Peiss, Kathy. "On Beauty ... and the History of Business.” Enterprise \& Society 1, no. 3 (September 2000): 485-506. doi:10.1093/es/1.3.485

Perry, Lara. "Looking Like a Woman: Gender and Modernity in the Nineteenth-Century National Portrait Gallery.” In English Art, 1860-1914: Modern Artists and Identity, edited by David Peters Corbett and Lara Perry, 116-132. Manchester, UK: Manchester University Press, 2000. 
Pointon, Marcia. "Portrait-Painting as a Business Enterprise in London in the 1780s." Art

History 7, no. 2 (June 1, 1984): 187-205. doi:10.1111/j.1467-

8365.1984.tb00140.x

Public Monuments and Sculpture Association. "Façade of The Gibson Hall (Formerly

National Provincial Bank), Bishopsgate,” September 14, 2016.

http://pmsa.org.uk/pmsa-database/570

Rafaeli, Anat, and Michael G. Pratt. "Tailored Meanings: On the Meaning and Impact of

Organizational Dress.” Academy of Management Review 18, no. 1 (January 1,

1993): 32-55. doi:10.5465/AMR.1993.3997506

Roper, Michael, and John Tosh. "Introduction. Historians and the Politics of

Masculinity." In Manful Assertions: Masculinities in Britain Since 1800, edited

by Michael Roper and John Tosh, 1-24. London: Routledge, 1991.

Royal Society. "Portrait of James William Gilbart." Royal Society Picture Library,

accessed September 14, 2016. https://pictures.royalsociety.org/image-rs-9573.

Rutterford, Janette. "From Dividend Yield to Discounted Cash Flow: A History of UK

and US Equity Valuation Techniques.” Accounting, Business \& Financial History

Commented [LMS2]: This seems odd here (it seems to be from an archive. Did you mean to put it elsehwere in the bibilo?

Commented [VB3R2]: We have only seen the online version

14, no. 2 (July 1, 2004): 115-149. doi:10.1080/0958520042000225745

. “'Propositions Put Forward by Quite Honest Men': Company Prospectuses and

Their Contents, 1856 to 1940.” Business History 53, no. 6 (October 1, 2011):

866-899. doi:10.1080/00076791.2011.590932 
Rutterford, Janette, and Josephine Maltby. "Frank Must Marry Money: Men, Women, and Property in Trollope's Novels." Accounting Historians Journal 33, no. 2 (December 2006): 169-199.

Tosh, John. "Masculinities in an Industrializing Society: Britain, 1800-1914.” Journal of British Studies 44, no. 2 (April 2005): 330-342. doi:10.1086/427129

Townsend-Gault, Charlotte. "Symbolic Façades: Official Portraits in British Institutions Since 1920.” Art History 11, no. 4 (December 1, 1988): 511-526. doi:10.1111/j.1467-8365.1988.tb00321.x van den Bosch, Annette L. M., Menno D. T. de Jong, and Wim J. L. Elving. "How Corporate Visual Identity Supports Reputation." Corporate Communications: An International Journal 10, no. 2 (June 1, 2005): 108-116. doi:10.1108/13563280510596925

Van Heerden, Cornelius H., and Gustav Puth. "Factors That Determine the Corporate Image of South African Banking Institutions: An Exploratory Investigation.” International Journal of Bank Marketing 13, no. 3 (May 1, 1995): 12-17. doi:10.1108/02652329510082979

Trade Journals

Bankers' Magazine

Bradford Observer

Drawing Room Portrait Gallery of Eminent Persons

Ibbetson's Directory of the Borough of Bradford

Illustrated London News 
Illustrated News of the World

The Innkeeper and Traveller

The London Review of Politics, Society, Literature, Art, \& Science

Manchester and Liverpool District Bankers’ Institute Magazine

Merchants Magazine

The Economist

The Morning Chronicle

The Morning Post

Royal Cornwall Gazette, Falmouth Packet, and General Advertiser

Archival Sources

Barclays Group Archives, Manchester, UK

Lloyds Banking Group Archives, London, UK

New York Public Gallery, New York, NY

HSBC Group Archives, London, UK

National Portrait Gallery, London, UK

RBS Heritage Archives, Edinburgh, Scotland

Royal Society Print, London, UK

Websites

Oxford Dictionary of National Biography 
${ }^{1}$ We are indebted to the ESRC (grant number: ES/J500148/1) for their financial support and to the bank archivists who have been of such immense assistance in helping us to find the portraits: Sara Kinsey (HSBC Group Archives), Sophia Volker (Royal Bank of Scotland Archives), Karen Sampson (Lloyds Banking Group Archives) and Maria Sienkiewicz (Barclays Archive). We also owe thanks to three anonymous referees for their comments and advice and to the audiences at the CHORD workshop on Retailing, Commerce and the Human Body: Historical Approaches in Wolverhampton in 2014, the 2014 Summer Workshop at the University of York Management School, the European Business History Association/Business History Conference in Miami in 2015, and the conference for the Association of Business Historians in Exeter in 2015.

${ }^{2}$ Lambert, "Corporate Identity."

${ }^{3}$ Markwick and Fill, "Towards a Framework”; Bickerton, “Corporate Reputation”; Schulz, Hatch, and Larsen, Expressive Organization; Einwiller and Will, "Towards an Integrated Approach"; van den Bosch, de Jong, and Elving, "Corporate Visual Identity." ${ }^{4}$ Firms in the service industry have also been found to be particularly conscious of their identity and reputations due to the fact they that are in direct and close contact with their customers. For example, "Most South African banks have well-designed corporate livery, smart buildings, and distinguishable corporate headquarters. Communicating a distinctive corporate identity is therefore a major means of achieving a unique positioning, which may lead to increased profits and improved business relationships with customers, suppliers, intermediaries, subsidiaries, the authorities, the media and international contacts." Van Heerden and Puth, "Factors That Determine the Corporate Image," $13 \underline{13}$. 
See also Wu, Privatising Culture; Hansen, "Organizational Culture and Organizational Change."

${ }^{5}$ See Baker and Balmer, "Visual Identity"; Balmer and Greyser, Revealing the Corporation.

${ }^{6}$ For more on the value of images, see Ames, "Material Culture"; Anderson, Cognitive Psychology; Schama, Face of Britain.

${ }^{7}$ Guthey and Jackson, "CEO Portraits."

${ }^{8}$ Despite the advantages of having unlimited owners, joint-stock banks were not given corporate status under the 1826 Bank Act. A corporation possessed limited liability, freely transferrable shares, and a separate legal personality. Joint-stock banks did not have these rights or powers and behaved in English company law as partnerships. Like a private bank, a joint-stock bank could neither enter into contracts in its own name nor have assets or liabilities that could be separated from that of its owners. For further discussion, see Cooke, Corporation, Trust and Company; Freeman, Pearson, and Taylor, "Law, Politics."

${ }^{9}$ Private banks, with their history and lineage, already had such associations with key individuals. Ackrill and Hannah, Barclays, chap. 1.

${ }^{10}$ Exceptions are Rutterford and Maltby, "Frank Must Marry Money”; Michie, Guilty Money, which each consider finance and investment through literary sources.

${ }^{11}$ Black, "Spaces of Capital"; Booker, Temples of Mammon.

${ }^{12}$ It is more difficult to document interior features as formal contracts because plans were not given for this activity in the same way as they were for the exterior. They rarely 
stayed static through the passage of time. Indeed, inventory lists and purchasing records from those country homes have been often been a key source in showing that goods were used in everyday life before photography became common. Thus, the portraits inside a bank archives serve as a form of inventory and evidence that the artifacts in it were used and created in the ordinary course of the bank's business.

${ }^{13}$ See Scammell, London Discount Market, 135. The Bank of England operated branches in the English provinces, so they were in direct competition with the new joint-stock banks. Private banks were also competing directly with the newcomers.

${ }^{14}$ They had to refute some of the broader and more damaging claims about the jointstock form, such a lack of confidentiality. Bailey, "Circular to Bankers"; Taylor, Creating Capitalism.

${ }^{15}$ Michie, Guilty Money; Taylor, Creating Capitalism; Wilson, Origins of Modern Financial Crime.

${ }^{16}$ For example, soon after its establishment in 1833 , the Nottingham and

Nottinghamshire Banking Company agreed to pay 2.5 percent interest on the deposit accounts. RBS Archives NOT/1/1, 7 April 1834. Private banks did not tend to offer interest on such accounts. See also Newton, "Birth of Joint-Stock Banking."

${ }^{17}$ When a merger occurred between $\mathrm{A}$ and $\mathrm{B}$, the result was not the creation of $\mathrm{C}$ but a continuation of either A or B (as defined by its name). The continuing bank, A or B, was usually a joint-stock bank. As Garnett, Mollan, and Bentley show in "Complexity in History," this was a good way for the joint-stock bank to obtain custom and assets.

However, it was the face of a joint-stock bank and its ownership structure that survived at 
the expense of the private bank. See Sykes, Amalgamation Movement, Appendices 1 and 2.

${ }^{18}$ For a discussion of prospectuses, promotion, and promises of shareholder control, see Alborn, Conceiving Companies, chap. 4; Rutterford, “'Propositions.”

${ }^{19}$ Companies were not required by statute law to keep books and publish balance sheets until 1844. Historians, like Napier, have asserted skepticism about the accuracy of these figures because auditors were not always impartial or trained in accountancy. See Napier, "United Kingdom."

${ }^{20}$ Rutterford, "Dividend Yield."

${ }^{21}$ Newton, "Birth of Joint-Stock Banking"; Newton and Barnes, "Virtuous Banking."

${ }^{22}$ The Bradford Observer, August 1, 1844. Laycock's portrait survives and is now kept at Bradford Art Galleries and Museums.

${ }^{23}$ Bankers' Magazine 6 (Oct. 1846-March 1847), 248.

${ }^{24}$ Laycock is listed as the manager of the Bradford Banking Company in the report that details the commission of his portrait. In others, he is also identified as chairman and a shareholder. See Cudworth, Historical Notes, 171. While Laycock may have held these positions at some point, it is unclear when, and the directories of the 1840s identify him as a manager, not as a chairman or shareholder.

${ }^{25}$ Orbell and Turton, British Banking, 112.

${ }^{26}$ Bankers' Magazine 6 (Oct. 1846-March 1847), 248.

${ }^{27}$ The portrait was proposed in 1844. By 1845, Laycock was listed as the manager of the Bradford Banking Company in Ibbetson's Directory of the Borough of Bradford (1845), 
98. Likewise Henry Luard, manager of the London and County Bank, was in office when directors commissioned his portrait. Bankers' Magazine 14 (January to December, 1854), 1. His career ended in scandal and his portrait does not appear to have been kept by the bank.

${ }^{28}$ Other banks in London, such as the Union Bank of London, followed suit. At the annual general meeting in 1854 , it was proposed and unanimously agreed that a portrait should be painted of the current governor of the bank, Sir Peter Laurie. He remained in this post until his death five years after his image was painted. Bankers' Magazine 14, (January to December, 1854), 467.

${ }^{29}$ Royal Cornwall Gazette, Falmouth Packet, and General Advertiser, March 21, 1851.

${ }^{30}$ Holmes and Green, Midland, 32.

${ }^{31}$ Crick and Wadsworth, Hundred Years, 421; Holmes and Green, Midland, Illustration 1.4; Kinsey, "Geach, Charles 1808-1854."

${ }^{32}$ Economist, Saturday, May 27, 1865, 59. The bust remains in Gibson Hall in the City of London, where the head office of the bank was located. See Public Monuments and Sculpture Association, "Façade of The Gibson Hall." A visit to Gibson Hall by Newton on July 28, 2016, confirmed the location. Thanks to Melissa Golberg of Gibson Hall for facilitating this visit.

${ }^{33}$ There are three portraits from the Birmingham Town and District Bank. One can instantly be identified as the image of George Bacchus by the large the bronze tag on the front, which states his name, dates of birth and death, and position within the bank. The other two portraits belonged to the Birmingham Town and District Bank collection but 
the identity of the sitters remains unknown. This information has not been recorded on a tag or anywhere else. As the frames are very similar, it seems likely that the three paintings were made as a set. As a result, these two paintings have been included (under "unknown") in Table 1.

${ }^{34}$ See, for example, the discussion of Samuel Laycock and Henry Luard, above. Many others are discussed in the following sections.

35 Bradford Observer, August 1, 1844.

${ }^{36}$ Royal Cornwall Gazette, Falmouth Packet, and General Advertiser, March 21, 1851.

${ }^{37}$ Bankers' Magazine 26 (January to December, 1866), 120.

${ }^{38}$ Plates were another traditional or customary gift on retirement. A set of silverware was presented to Mr. Ewing in 1860 by his branch customers on his promotion to general manager at the London and Westminster Bank (to replace Gilbart). Mr. Laurd, general manager of the London and County Bank, was presented a set of silverware by his branch managers and fellow officers in 1853. Illustrated London News, March 24 1860, 277, and November 5, 1853, 382.

${ }^{39}$ When noting that the shareholders voted to give a plate, which cost $£ 200$, the writers of an article in the London Review of Politics admitted, "We rubbed our eyes ... It appeared to us as a typographical mistake." On learning that the figure was correct, they suggested, “[It] should be, at least $£ 2,000$.” London Review of Politics (1863), 67. By comparison, Geach’s plate was worth $£ 1,500$. The bank gifted the plate as well as a portrait. Royal Cornwall Gazette, Falmouth Packet, and General Advertiser, March 21, 1851.

${ }^{40}$ Bradford Observer, August 1, 1844. 
${ }^{41}$ Royal Cornwall Gazette, Falmouth Packet, and General Advertiser, March 21, 1851.

${ }^{42}$ Illustrated London News, November 6, 1852.

${ }^{43}$ Kinsey, "Geach, Charles (1808-1854)."

${ }^{44}$ Bankers' Magazine 14 (January to December, 1854), 467. It does not survive in the bank archives.

${ }^{45}$ McConnell, "Laurie, Sir Peter (1778-1861)."

${ }^{46}$ Holmes and Green, Midland, 30-31.

${ }^{47}$ The portraits of Hodgson and Holt can be found in Chandler, Four Centuries of

Banking, 234 and 241. Both are held by Barclays Bank Group Archives, reference 12710016 (Hodgson) and 1271-0017 (Holt).

${ }^{48}$ Ellison, Cotton Trade, 202; Chandler, Four Centuries of Banking, 239, 250-251, 276.

Crick and Wadsworth list the successful business interest of the pioneering Yorkshire joint-stock bankers. Crick and Wadsworth, Hundred Years, 205.

${ }^{49}$ These acts were not assessed in any formal way or frequently enough to be measured or compared with any previous attempt.

${ }^{50}$ For example, the image of Ben Wilson, one of the founders of the Mirfield and Huddersfield District Bank, was located in the Mirfield Branch, and the image of Joseph Wheatley, first chairman of the West Riding Union Banking Company, founded in 1836, was kept in the Huddersfield branch. Anon., Story of the Lancashire \& Yorkshire Bank, $50 \mathrm{~b}$.

${ }^{51}$ Robertson's face was encapsulated in a bust rather than a portrait in the head office, now known as Gibson Hall, a popular London events venue and a Grade I listed building. 
Figure 3 shows Robertson's bust in its original site, an alcove facing the front entrance of the building.

${ }^{52}$ Economist, May 27, 1865, 59

${ }^{53}$ For more detail and discussion, see Black, "Symbolic Capital."

${ }^{54}$ Bankers' Magazine 14 (January to December, 1854), 467; Royal Cornwall Gazette, Falmouth Packet, and General Advertiser, March 21, 1851.

55 Newton and Barnes, "Virtuous Banking."

56 Carnevali, "Between Markets and Networks."

${ }^{57}$ For a description of New England, see Lamoreaux, Insider Lending.

${ }^{58}$ A guide to Manchester explained that Burdekin was also personally to blame for the failure of the bank in 1843, and that "many of the losses were sustained in consequence of the lenience shown by him to a number of personal friends." Swindells, Manchester Streets, 281.

${ }^{59}$ Bankers' Magazine 3 (January to December, 1846), 121.Following this, it published portraits on a fairly regular basis and this became an important point in its own advertisements. See Morning Chronicle, November 1, 1847; Morning Post, February 4, 1850.

${ }^{60}$ Bankers' Magazine 9 (January to December, 1849), inside cover.

${ }^{61}$ Merchants Magazine 19, no. 1 (July-December 1848), inside cover.

${ }^{62}$ Royal Society, "Portrait of James William Gilbart."

${ }^{63}$ Illustrated News of the World, January 14, 1860; Drawing Room Portrait Gallery of Eminent Persons (3rd series, 1860). 
${ }^{64}$ Gilbart, Record of the Proceedings.

65 Illustrated London News, Saturday, November 14, 1863.

66 Ibid.

${ }^{67}$ British Museum, "James William Gilbart (Biographical Details).”

${ }^{68}$ Gilbart, Elements of Banking, 179-180.

${ }^{69}$ A counter example may be Geach, who was from the Birmingham and Midland Bank.

He appeared in the Illustrated London News, although this feature may have had more to do with his position in Westminster as an MP than with his role as a banker in

Birmingham. The illustration appears to be a copy of Figure 2. Illustrated London News, Saturday, November 6, 1852.

${ }^{70}$ RBS Archives, NAT/1313, two portraits of Daniel Robertson, first general manager and director (1833-1864).

${ }^{71}$ Engravings were taken from the original portrait and given to each shareholder.

Bradford Observer, August 1, 1844.

72 Marx, Capital, 641.

${ }^{73}$ Gilbart began his career in banking at the Provincial Bank of Ireland, at a branch in Waterford. It was there that he, along with a number of others, created the Waterford Literary and Scientific Institution. Merchants Magazine 19, no. 1 (July-December 1848): 69.

74 “Books Received," Innkeeper and Traveller 1 (1861): 100.

${ }^{75}$ For example, in Townsend-Gault's view, it was the act of commissioning that showed that the institution endorsed the sitter. The sitter, by agreeing to be recorded, showed the 
sitter's reciprocal approval of the institution. The portrait, therefore, demonstrated that the two were in agreement and became synchronized. The mutual act of authorizing the portrait, Bourdieu argued, ensured that the two shared whatever cultural capital would be gained from the portrait itself. See Townsend-Gault, "Symbolic Façades"; Bourdieu, Outline of a Theory of Practice.

${ }^{76}$ Indeed, in most cases, the two generally went together; the act of purchasing goods usually gave the buyer the rights to title, possession, and use.

${ }^{77}$ Bayer and Page, Development of the Art Market, chaps. 6 and 7.

78 Townsend-Gault, “Symbolic Façades,” 517-519.

79 Pointon, "Portrait-Painting."

${ }^{80}$ Pointon has shown that portraiture was the most common type of artwork submitted to the Royal Academy between 1781 and 1785. Ibid., 188-189, 203; West, Portraiture, 12. ${ }^{81}$ An interesting difference existed in the portraits of men and women. Male portraits were accompanied by a biography of the sitter, whereas in the case of a female portrait, biographies tended to emphasize the role of the painter. Perry, "Looking Like a Woman," $128-129$.

${ }^{82}$ Barlow, "Facing the Past and Present," 224.

83 Townsend-Gault, "Symbolic Façades," 516.

${ }^{84}$ Yamey, Art and Accounting, 32-35. Thanks to John Board for this reference.

85 Townsend-Gault, "Symbolic Façades," 516.

${ }^{86}$ Foucault, Power/Knowledge, 61.

${ }^{87}$ Griffey and Jackson, "Portrait as Leader." 
${ }^{88}$ Townsend-Gault, "Symbolic Façades,” 516.

${ }^{89}$ Harris, Cultural Excursions, chap. 17.

${ }^{90}$ Griffey and Jackson, "Portrait as Leader," 134, 136.

${ }^{91}$ Peiss, "On Beauty," 497. See also McCracken, Culture and Consumption, 66; Rafaeli and Pratt, "Tailored Meanings."

${ }^{92}$ See Byrde, Male Image; De Marly, Fashion for Men.

${ }^{93}$ Craik, Face of Fashion, 184.

${ }^{94}$ Kidwell, "Gender Symbols,” 129.

${ }^{95}$ Hollander, Sex and Suits, 113, 151.

${ }^{96}$ Davidoff and Hall, Family Fortunes, 410-412.

${ }^{97}$ Breward, Hidden Consumer, 86-88.

${ }^{98}$ Ibid., 88.

${ }^{99}$ Shannon, Cut of His Coat, 25.

100 Tosh, "Masculinities," 332.

101 Griffey and Jackson, "Portrait as Leader," 140.

102 Wilson, Healthy Skin, 101.

${ }^{103}$ Robinson, City Banker, 50.

104 Roper and Tosh, "Historians and the Politics of Masculinity," 18.

105 Burke, Eyewitnessing, 25.

106 Graves, "Partridge, John (1789-1872)”; Perry, "Looking Like a Woman,” 122.

107 Griffey and Jackson, “Portrait as Leader,” 140. 
${ }^{108}$ Barclays Bank Group Archives, 1271-0016 (Hodgson) and 1271-0017 (Holt). The portraits are hung at Barclays Technology Centre, Radbroke Hall, Knutsford, Cheshire, UK.

109 The movement to standardize banking behavior in the form of a national professional body that could offer education and training in banking skills had been building from the 1850s. It led to the founding of a short-lived Banking Institute, from 1851 to 1853 , and a proposed Incorporation of Bankers in 1862. Finally, after the City of Glasgow Bank failure, the Institute of Bankers was founded in 1879. See Green, Debtors.

${ }^{110}$ For the use of portraits of professionals in the eighteenth century, see Nenadic, "Portraits of Scottish Professional Men."

111 Townsend-Gault, “Symbolic Façades,” 516.

112 Yamey, Art and Accounting, 21-43.

113 Burke, Eyewitnessing, 26.

${ }^{114}$ Nicolson, Joseph Wright of Derby, 163.

115 Davison, “[In]visible [In]tangibles,” 173.

116 Ponsonby provides an excellent study of the contents of the home before the advent of photography. See Ponsonby, Stories from Home.

${ }^{117}$ Breward, Hidden Consumer, 77.

${ }^{118}$ Even this artwork can still provide organizational signaling. Hoeken and Ruikes, "Art for Art's Sake?" 